\title{
Organic carbon in agricultural soils of the Mexican tropics
}

\author{
Leticia C. López-Teloxa ${ }^{1 *}$ \\ Alejandro I. Monterroso-Rivas ${ }^{2}$ \\ Jesús D. Gómez-Díaz²
}

\begin{abstract}
Soil organic carbon (SOC) is an indicator of soil health, so it is a priority to study it. The objective of this paper is to show the crops that have been studied and reported on for their SOC content in Mexico's tropical region. For this, published scientific references for the states of the Yucatan Peninsula, Guerrero, Veracruz, Oaxaca, Tabasco and Chiapas were consulted. The documents were grouped according to use and intensity of agricultural production and descriptive statistical values were estimated. Results indicate that out of a total of 164 crops there is evidence that 21 have been studied. SOC contents are displayed, ranging from 0.8 to $16 \%$. Agricultural activities that modify SOC content are also highlighted. Finally, the potential for future work and recommendations for priority research areas are analyzed.
\end{abstract}

Keywords: Agroecosystem; mitigation; soil management; soil conservation.

\section{Carbono orgánico en suelos agrícolas del trópico mexicano}

\section{Resumen}

Un indicador del estado de salud de los suelos es el carbono orgánico en suelos (COS), por lo que es prioritario estudiarlo. El objetivo del trabajo es mostrar los cultivos que han sido estudiados y reportados en su contenido de COS para la región tropical de México. Para ello, se consultaron referencias científicas publicadas para los estados de la Península de Yucatán, Guerrero, Veracruz, Oaxaca, Tabasco y Chiapas. Los documentos fueron agrupados según uso e intensidad de la producción agrícola y se estimaron valores estadísticos descriptivos. Los resultados indican que de un total de 164 cultivos se tiene evidencia de 21 que han sido estudiados. Se muestran los contenidos de COS, que van desde 0.8 y hasta $16 \%$. También se resaltan las actividades agrícolas que modifican el contenido de COS. Finalmente, se analizan potencialidades de trabajos futuros y recomendaciones de investigación que derivan como prioritarias.

Palabras clave: Agroecosistema; mitigación; manejo del suelo; conservación de suelo.

\footnotetext{
'Universidad Autónoma Chapingo, Departamento de Fitotecnia, km 38.5 carretera México-Texcoco, Chapingo, Texcoco, Estado de México. C.P. 56230

2Universidad Autónoma Chapingo, Departamento de Suelos, km 38.5 carretera México-Texcoco, Chapingo,

Texcoco, Estado de México. C.P. 56230

* Corresponding author: citlaly_lo@hotmail.com

Date received: May 30, 2019

Date accepted: January 28, 2020
} 


\section{Introduction}

One indicator of the health status of soils is soil organic carbon (SOC). It favors the amount, availability and solubility of soil nutrients for plant growth, and even modifies acidity and alkalinity towards values close to neutrality (Martínez, Fuentes, \& Acevedo, 2008). SOC is the main component of soil organic matter (SOM) as it provides high cation and nutrient exchange capacity colloids (FAO \& ITPS, 2018). It modifies the structure and distribution of the pore space in soil (Vela, López, \& Rodríguez, 2012, Wang, Kang, Cheng, \& Han, 2016). In summary, SOC improves soil quality and consequently enhances agricultural productivity (Roldán, Salinas, Alguacil, \& Carbaca, 2007). Soils represent the largest global carbon reservoir as they store at least three times as much $C$ as either the atmosphere or plants (Schmidt, et al. 2011), hence the loss of SOC is suggested as an indicator of soil degradation. Therefore, it is important to conserve SOC as well as the ecosystem service it provides in the capture and storage of carbon by ecosystems (Palm, Blanco, DeClerck, Gatere, \& Grace, 2014).

Terrestrial ecosystems act as an emission source, but also as sinks for carbon dioxide $\left(\mathrm{CO}_{2}\right)$, nitrous oxide $\left(\mathrm{N}_{2} \mathrm{O}\right)$ and methane $\left(\mathrm{CH}_{4}\right)$, all greenhouse gases. However, depending on local geology, climatic conditions and land use (among others), ecosystems more or less conserve these gases, playing an important role in their global balance and in global warming of the Earth (García et al., 2004). Climate plays a major role as an intervener in the $\mathrm{C}$ cycle in terrestrial biomes (Galicia et al., 2015). For example, soils in tropical conditions account for $30 \%$ of the global SOC pool with 384-506 Pg at $1 \mathrm{~m}$ depth (Bonan, 2008, Malhi \& Phillips, 2004, Molina, Pérez, Krishnamurty, Pérez, \& Miguel, 2012). Due to their high rates of SOM fixation and decomposition, these conditions participate in a large proportion of the global terrestrial cycle of this bioelement and its storage (Pan et al., 2011). Lal (2002) found that tropical forests contain $32 \%$ of the $\mathrm{C}$ of terrestrial ecosystems in ice-free zones. Unfortunately, a large part of $\mathrm{C}$ emissions to the atmosphere come from deforestation of these forests (Galicia et al., 2015). This deforestation occurs mainly for agricultural purposes.

Agricultural practices should be environmentally friendly and not aggravate climate change. When

\section{Introducción}

Un indicador del estado de salud de los suelos es el carbono orgánico en suelos (COS). Favorece la cantidad, disponibilidad y solubilidad de nutrientes del suelo para el crecimiento de las plantas, incluso, modifica la acidez y alcalinidad hacia valores cercanos a la neutralidad (Martínez, Fuentes, \& Acevedo, 2008). El COS es el componente principal de la materia orgánica del suelo (MOS) proporcionando coloides de alta capacidad de intercambio catiónico y de nutrientes (FAO \& ITPS, 2018). Modifica la estructura y la distribución del espacio poroso del suelo (Vela, López, \& Rodríguez, 2012; Wang, Kang, Cheng, \& Han, 2016). En resumen, el COS mejora la calidad del suelo y en consecuencia favorece la productividad agrícola (Roldán, Salinas, Alguacil, \& Carbaca, 2007). Los suelos representan el mayor reservorio global de Carbono almacenando al menos tres veces más C que el que hay en la atmósfera o plantas (Schmidt et al., 2011), de ahí que la pérdida de COS sea sugerida como indicador de degradación del suelo. Por lo anterior, es importante conservar el COS así como el servicio ecosistémico que brinda en la captura y almacenamiento de carbono por los ecosistemas (Palm, Blanco, DeClerck, Gatere, \& Grace, 2014).

Los ecosistemas terrestres actúan como fuente de emisión, pero también como sumideros de dióxido de carbono $\left(\mathrm{CO}_{2}\right)$, óxido nitroso $\left(\mathrm{N}_{2} \mathrm{O}\right)$ y metano $\left(\mathrm{CH}_{4}\right)$, todos los gases efecto invernadero. Sin embargo, dependiendo de la geología local, las condiciones climáticas y el uso del territorio (entre otros), los ecosistemas conservan más o menos estos gases, jugando un papel importante en el balance global de los mismos y en el calentamiento global de la Tierra (García et al., 2004).

El clima juega un papel principal como interventor del ciclo del $C$ en los biomas terrestres (Galicia et al., 2015). Por ejemplo, los suelos en condiciones tropicales representan el $30 \%$ del almacén global del COS con 384-506 Pg a $1 \mathrm{~m}$ de profundidad (Bonan, 2008; Malhi \& Phillips, 2004; Molina, Pérez, Krishnamurty, Pérez, \& Miguel, 2012). Debido a sus elevadas tasas de fijación y descomposición de la MOS estas condiciones participan en una gran proporción del ciclo global terrestre de este bioelemento y de su almacenamiento (Pan et al., 2011). Lal (2002) encontró que los bosques tropicales contienen el $32 \%$ del C 
SOM decomposes, $\mathrm{C}$ is emitted into the atmosphere. If this occurs at too high a rate, soils can contribute to global warming. On the other hand, many soils have the potential to increase their SOC reserves, mitigating climate change (FAO \& ITPS., 2018). Activities such as type of tillage, waste management and crop rotation are crucial determinants of the amount of carbon sequestered in the soil. For example, the top soil of fields under zero tillage with residue retention has a larger $\mathrm{SOC}$ content and a lower SOM decomposition rate than soil with conventional tillage (Fuentes et al., 2012). On the other hand, crop rotation can affect SOC because the content depends on the type of crop in the rotation, the quality and quantity of crop residues and root development (Wright \& Hons, 2005). Since crop residues are precursors of the SOM pool, the incorporation of more crop residues into the soil is associated with an increase in SOC concentration (Martínez et al. 2008, Wright \& Hons, 2005).

Therefore, it is important to know the SOC content in the country's soils and agricultural systems, as well as those management practices that modify and affect soil production and conservation. The objective of this paper is to document studies showing the status of $\mathrm{SOC}$ in agricultural soils in Mexico's tropical region, highlighting the agricultural activities that characterize them in order to analyze the potential for future work and recommend priority research areas.

\section{Status of SOC in agricultural soils in the tropical region of Mexico}

\section{Compilation of published scientific articles related to SOC}

The study area was several states comprising the Mexican tropics: Oaxaca, Veracruz, Chiapas, Tabasco, Campeche, Quintana Roo and Yucatán. The study particularly focused on the agricultural soils of these states. Studies suggest that the region may be seriously affected by the impact of climate change, even to the point of losing all profit or income (SAGARPA-FAO, 2014).

Agricultural activity in the states is carried out in the two growing seasons: spring-summer and autumn-winter, under both rainfed and irrigated de los ecosistemas terrestres en zonas libres de hielo. Desafortunadamente, una gran parte de las emisiones de $\mathrm{C}$ a la atmósfera provienen de la deforestación de estos bosques (Galicia et al., 2015). Deforestación que ocurre principalmente para fines agrícolas.

Las prácticas agrícolas deben ser respetuosas del entorno y no agravar el cambio climático. Cuando se descompone la MOS, se emite $\mathrm{C}$ a la atmósfera. Si esto ocurre a tasas demasiado altas, los suelos pueden contribuir al calentamiento global. Por otro lado, muchos suelos tienen el potencial para aumentar sus reservas de COS, mitigando el cambio climático (FAO \& ITPS., 2018). Actividades como el tipo de labranza, manejo de residuos y la rotación de cultivos son determinantes cruciales de la cantidad de carbono retenido en el suelo. Por ejemplo, el suelo superior de los campos bajo labranza cero con retención de residuos tiene mayor COS y una tasa de descomposición de MOS más baja que el suelo con la labranza convencional (Fuentes et al., 2012). Por otro lado, la rotación de cultivos puede afectar el COS, porque el contenido depende del tipo de cultivo en la rotación, la calidad y cantidad de residuos de cultivos y el desarrollo de la raíz (Wright $\&$ Hons, 2005). Dado que los residuos de cultivos son precursores de la reserva de MOS, la incorporación de más residuos de cultivos al suelo se asocia con un aumento en la concentración de COS (Martínez et al., 2008; Wright \& Hons, 2005)

Por lo anterior, es importante conocer el contenido de COS en los suelos y sistemas agrícolas del país, así como aquellas prácticas de manejo que modifican y afectan la producción y conservación de suelo. El objetivo de este trabajo es documentar los estudios que muestran el estado del $\operatorname{COS}$ en suelos agrícolas de la región tropical de México, resaltando las actividades agrícolas que los caracterizan con el propósito de analizar las potencialidades de trabajos futuros $y$ las recomendaciones de investigación que derivan como prioritarias.

\section{Estado del cos en suelos agrícolas de la región tropical de México}

\section{Recopilación de artículos científicos publicados relacionados con el COS}

El área de estudio fueron algunos estados que comprenden el trópico mexicano: Oaxaca, Veracruz, 
conditions (SIAP, 2017). Agricultural activity in the region is very diverse and varied. For example, in the first cycle, Campeche grows rice, squash, green chili pepper, corn, and other crops. Chiapas sows beans, corn, sorghum, and soybeans, among others. Guerrero produces squash, beans, corn, sorghum and others. In Oaxaca they also plant corn, beans, sorghum and wheat. Quintana Roo mainly grows corn, beans, squash and chili pepper. In Tabasco, Veracruz and Yucatan, corn, beans, squash, and rice, among others, are planted. For the autumnwinter cycle, the crops are also varied and it is worth mentioning that there are also perennial crops such as sugarcane, lemon, mango, orange, grasses, cocoa, coffee, coconut, banana, avocado and henequen, among others. In total, SIAP (2017) reports just over 150 crops in the states analyzed.

Once the study area was delimited, the detailed and systematic method of exploration and structured search for information was defined. First, the key words to be identified were defined: "agriculture", "agroforestry", "carbon", "soil organic carbon", "carbon content", "crops", "soil organic matter" and "Mexico". The systematic review was for scientific articles and indexed journals. Six scientific databases were searched: Web of Science, Science Direct, Google Scholar, Scopus, and Regional Online Information System for Scientific Journals in Latin America, the Caribbean, Spain and Portugal, as well as Scientific Electronic Library Online. Other authors have suggested searching the aforementioned databases (Martínez, Alvarado, Zamudio, \& Cristobal, 2017, Pompa \& Sigala, 2017, Saynes, Etchevers, Paz, \& Alvarado, 2016, Zasada, 2011). It should be noted that the results from gray literature (theses, technical reports, conferences, abstracts, seminars and scientific meetings) were excluded from the results.

We used different combinations of keywords from a predefined list, as in indexed and peerreviewed journals published until December 2018. The information collected was classified by state, selecting those corresponding to the tropical zone, defined as the states of Campeche, Chiapas, Guerrero, Oaxaca, Quintana Roo, Tabasco, Veracruz and Yucatán. Published works were delimited in time to the last 30 years.
Chiapas, Tabasco, Campeche, Quintana Rooy Yucatán. Particularmente el estudio se focalizó en los suelos agrícolas de dichas entidades. Los estudios sugieren que la región puede verse seriamente afectada por el impacto del cambio climático hasta incluso, perder cualquier ganancia o ingreso (SAGARPA-FAO, 2014).

La actividad agrícola en los estados se lleva a cabo en los dos ciclos: primavera-verano y otoñoinvierno, tanto en condiciones de temporal como de riego (SIAP, 2017). La actividad agrícola en la región es muy diversa y variada. Por ejemplo, en el primer ciclo, Campeche siembra arroz, calabaza, chile verde, maíz y otros cultivos. Chiapas siembra frijol, maíz, sorgo, soya entre otros. En Guerrero la actividad produce calabaza, frijol, maíz, sorgo y otros. En el estado de Oaxaca también se siembra maíz, frijol, sorgo y trigo. Quintana Roo domina el maíz, frijol, calabaza y chile. En Tabasco, Veracruz y Yucatán se siembran, principalmente, maíz, frijol, calabaza, arroz entre otros. Para el ciclo otoño-invierno los cultivos también son variados y no está demás comentar que también hay cultivos perennes como caña de azúcar, limón, mango, naranja, pastos, cacao, café, coco, plátano, aguacate y henequén, entre otros. En total SIAP (2017) reporta poco más de 150 cultivos en los estados analizados.

Toda vez que se delimitó el área de estudio se definió el método detallado y sistemático de exploración y búsqueda estructurada de información. Primero se definieron las palabras clave a ser identificadas: "agricultura", "agroforestería", "carbono", "carbono orgánico del suelo", "contenido de carbono", "cultivos", "materia orgánica del suelo" y "México". La revisión sistemática fue para artículos científicos y revistas indexadas. Se realizó la búsqueda en seis bases de datos científicas: Web of Science, Science Direct, Google Scholar, Scopus, Sistema regional de información en línea para revistas científicas de América Latina, El Caribe, España y Portugal, así como Scientific Electronic Library Online. Lo anterior tal como otros autores lo han sugerido (Martínez, Alvarado, Zamudio, \& Cristobal, 2017; Pompa \& Sigala, 2017; Saynes, Etchevers, Paz, \& Alvarado, 2016; Zasada, 2011). Cabe señalar que los resultados provenientes de literatura gris (tesis, informes técnicos, conferencias, resúmenes, seminarios y reuniones científicas) fueron excluidos de los resultados. 
All articles were downloaded to a hard disk and a database of documents was built up, including: 1) the description of the site studied;2) the type of crop; and 3) estimates of soil organic carbon stored in the first $30 \mathrm{~cm}$ of depth, expressed as a percentage. The above was done for all studies to ensure the reliability and comparability of the review data.

The crops reported in the review were classified according to intensity of use into five groups: 1) Polycultures with corn (PLC), which refers to corn with oats and broad beans, corn with cowpea, corn with potato, corn with broad beans, milpa (corn, beans and squash), milpa with trees or taungya; 2) Rainfed agriculture (RAG), which refers to corn, conservation corn, pastureland, sugarcane or potato; 3) Coffee (COF), corresponding to shade coffee or shadeless coffee; 4) Fruit trees (FRU), relating to mango, banana with forage peanut (Arachis pintoi), papaya with citrus, or pineapple; and finally, 5) Others (OTR), which groups Agave aungustifolia Haw., agroforestry systems with cocoa, home garden with cedar, cedar monoculture and cedar with mahogany and ginger.

With the studies and crops analyzed, an analysis of variance (ANOVA) was carried out to identify statistically significant differences in SOC values between different crops and states. Significant differences between the means of the crops and states were identified by the Tukey test at $P<0.05$. As suggested by other authors (Álvarez, 2005, Pompa \& Sigala, 2017), all statistical analyzes were performed with Minitab R 16.1.0 software (2010 Minitab Inc.).

\section{Current overview of the study of SOC in agricultural soils in Mexico's tropical region}

According to information from the National Institute of Statistics and Geography, INEGI (2007) and the Agri-food and Fisheries Information Service, SIAP (2017), around 164 types of crops are grown in the country's tropical region. Of these, it was found that information related to the determination of SOC content is reported for only 21 crops or associations (12.8\%). The total number of studies reported in the scientific databases was 35 , although by including those at the thesis or conference level the number would undoubtedly increase considerably. Most of them were published in the last seven years (Supplementary information Annex 1).
Se utilizaron diferentes combinaciones de una lista predefinida de palabras clave, como en revistas indexadas y revisadas por pares que se publicaron hasta diciembre de 2018. La información recabada se clasificó por estados, seleccionando los correspondientes a la zona tropical, definida como los estados de Campeche, Chiapas, Guerrero, Oaxaca, Quintana Roo, Tabasco, Veracruz y Yucatán. Los trabajos publicados se delimitaron en tiempo para los últimos 30 años.

Todos los artículos fueron descargados a un disco duro y se construyó una base de datos de los documentos, incluyendo: 1) la descripción del sitio estudiado; 2) el tipo de cultivo; y 3) las estimaciones de carbono orgánico del suelo almacenado en los primeros $30 \mathrm{~cm}$ de profundidad, expresados en porcentaje. Lo anterior para todos los estudios con el fin de garantizar la fiabilidad y la comparabilidad de los datos de la revisión.

Los cultivos reportados en la revisión se clasificaron de acuerdo con la intensidad de uso en cinco grupos: 1) Policultivos con maíz (PLM) que se refiere a maíz con avena y haba, maíz con frijol chino, maíz con papa, maíz con haba, milpa (maíz, frijol y calabaza), milpa con árboles o taungya; 2) Agricultura de temporal (AGT) que se refiere a maíz, maíz de conservación, pastizal, caña o papa; 3) Café (CAF) que corresponde a café a la sombra o café sin sombra; 4) Frutales (FRU) que corresponden a mango, plátano con cacahuate forrajero (Arachis pintoi), papaya con citrus, o piña; por último, 5) Otros (OTR) que agrupan a Agave aungustifolia Haw., sistemas agroforestales con cacao, huerto casero con cedro, monocultivo de cedro y cedro con caoba y jengibre.

Con los estudios y cultivos analizados se realizó un análisis de varianza (ANOVA) para identificar diferencias estadísticamente significativas en los valores de COS entre diferentes cultivos y entidades federativas. Las diferencias significativas entre las medias de los cultivos y entidades federativas se identificaron mediante la prueba de Tukey en $\mathrm{P}<$ 0.05. Tal como lo sugieren otros autores (Álvarez, 2005; Pompa \& Sigala, 2017), todos los análisis estadísticos se realizaron con el software Minitab R 16.1.0. (2010 Minitab Inc.). 
The states for which we found the greatest number of publications (68\%) reporting SOC are Oaxaca, Veracruz and Tabasco, with 11, 7 and 6 respectively. The states with one publication each are Quintana Roo and Yucatan. On the other hand, of the total number of publications, $45 \%$ (16) were for rainfed crops with corn, conservation corn, pastureland, sugarcane and potato. Thirty percent of the studies (11) were carried out on land with polycultures associated with corn, such as cowpea, potato and broad beans, as well as milpa, milpa with trees and agroforestry system (taungya).

Regarding SOC content, the results are presented in Table 1. It can be seen that the variety of crops and management practices included lead to important variations in SOC, although statistically they do not represent significant differences $(P>0.05)$. The crop with the highest reported SOC content is potato, while the lowest is the corn-oats-broad bean association, both for the state of Veracruz. The complete list is shown in supplementary information (Appendix 2).

Figure 1 shows the reported SOC content by state and type of crop. Rainfed agriculture or in some type of association is the one that predominates in the studies. On the other hand, it is well known that climate and soil type are determining factors for the production of certain foods, which also characterizes each of the states, as is the case of the coffee found in Chiapas and Oaxaca. However, according to INEGI (2007) and SIAP (2017), there is also significant coffee production in Veracruz and Guerrero, but no publication was found that refers to SOC content. Also, corn production under rainfed conditions is an important agricultural activity for most farmers in Mexico, which indicates the importance of a good rainy season for agriculture (Conde, Ferrer, \& Orozco, 2006).

On the basis of Figure 1, it can be interpreted that the state that reports the greatest agricultural diversity with reported SOC studies is Oaxaca, followed by Chiapas. The highest reported SOC value is for Yucatan and Veracruz, with 7.64 and $7.6 \%$, respectively. On the other hand, the state with the lowest SOC value is Guerrero (1.1\%). However, the states of Yucatán, Quintana Roo and Guerrero show a significant lag in terms of studies carried out on the subject; moreover, those that have been conducted are mainly on crops associated with corn.

\section{Panorama actual del estudio de $\operatorname{COS}$ en suelos agrícolas de la región tropical de México}

De acuerdo con información del Instituto Nacional de Estadística y Geografía, INEGI (2007) y del Servicio de Información Agroalimentaria y Pesquera, SIAP (2017), en la región tropical del país se cultivan alrededor de 164 tipos de cultivos. De los anteriores, se encontró que para 21 cultivos o asociaciones (12.8 $\%)$ se reporta información relacionada con la determinación de contenido de COS. El total de estudios reportados en las bases de datos científicas fue de 35 , aunque seguramente a nivel tesis o congresos el número aumenta considerablemente. La mayoría de ellos fueron publicados en los últimos siete años (Información complementaria Anexo 1).

Los estados para los que se encontró mayor número de publicaciones (68 \%) que reportan COS son Oaxaca, Veracruz y Tabasco, con 11, 7 y 6 respectivamente. Los estados con una publicación cada uno son Quintana Roo y Yucatán. Por otro lado, del total de publicaciones, el $45 \%$ (16) se realizó para cultivos de temporal con maíz, maíz de conservación, pastizal, caña y papa. El $30 \%$ de los estudios (11) se realizó en tierras con policultivos asociados con maíz como son frijol chino, papa y haba, así como milpa, milpa con árboles y sistema de agrosilvicultura (taungya).

En lo que se refiere al contenido de cOS los resultados se presentan en el Cuadro 1. Se observa que la variedad de cultivos y prácticas de manejo incluidas conducen a variaciones importantes en el COS, aunque estadísticamente no representan diferencias significativas $(P>0.05)$. El cultivo que más contenido de COS reporta es papa, mientras que el menor es la asociación maíz, avena y haba, ambos para el estado de Veracruz. El listado completo se muestra en información complementaria (Anexo 2).

En la Figura 1 se presenta el contenido reportado de COS por estado y tipo de cultivo. La agricultura de temporal o en algún tipo de asociación es la que predomina en los estudios. Por otro lado, es bien sabido que el clima y tipo de suelo son condicionantes para la producción de ciertos alimentos, lo que además caracteriza a cada uno de los estados, como es el caso del café que se encontró en Chiapas y Oaxaca. Sin embargo, de acuerdo al INEGI (2007) y SIAP (2017), en Veracruz y Guerrero también existe una importante 
Table 1. Soil organic carbon content according to crops and sources analyzed.

Cuadro 1. Contenido de carbono orgánico en suelo de acuerdo con cultivos y fuentes analizadas.

\begin{tabular}{|c|c|c|c|c|}
\hline State/Entidad & Dominant soils/Suelos dominantes & Crop/Cultivo & $\begin{array}{l}\% \mathrm{SOC} / \\
\% \operatorname{COS}\end{array}$ & Source/Fuente \\
\hline Veracruz & $\begin{array}{l}\text { Andosol and Cambisol (WRB)./ } \\
\text { Andosol y Cambisol (WRB). }\end{array}$ & $\begin{array}{l}\text { Corn associated with oats and } \\
\text { broad beans. / Maíz asociado } \\
\text { con Avena y Haba. }\end{array}$ & $0.66 \pm 0.12$ & Gamboa \& Galicia, 2011, 2012. \\
\hline Tabasco & $\begin{array}{l}\text { Gleysol, Vertisol, Cambisol, Luvisol, Acrisol, } \\
\text { Leptosol and Regosol (WRB)/ } \\
\text { Gleysol, Vertisol, Cambisol, Luvisol, Acrisol, } \\
\text { Leptosol y Regosol (WRB) }\end{array}$ & $\begin{array}{l}\text { Papaya with citrus./ } \\
\text { Papaya con cítricos. }\end{array}$ & $1.12^{*}$ & Geissen et al., 2009. \\
\hline Tabasco & Fluvisol (WRB). & $\begin{array}{l}\text { Banana with A. pintoi./ } \\
\text { Plátano con A. pintoi. }\end{array}$ & $1.18^{*}$ & Ramos et al., 2011. \\
\hline Tabasco & $\begin{array}{l}\text { Gleysol, Vertisol, Regosol, Luvisol and Leptosol } \\
\text { (WRB)./Gleysol, Vertisol, Regosol, Luvisol y } \\
\text { Leptosol (WRB). }\end{array}$ & Sugarcane /Caña & $1.25 \pm 0.36$ & $\begin{array}{l}\text { Geissen et al., 2009, Sánchez } \\
\text { et al., } 2003 .\end{array}$ \\
\hline Oaxaca & Leptosol and Regosol. & Agave angustifolia Haw. & $1.43 \pm 1.46$ & Bautista et al., 2007, 2015. \\
\hline Tabasco, Guerrero & Gleysol (WRB). & Cocoa AFS/Safa cacao & $1.46^{*}$ & $\begin{array}{l}\text { Cervantes et al., 2014, Salvador } \\
\text { et al., } 2017 .\end{array}$ \\
\hline Oaxaca, Guerrero & N.S. & $\begin{array}{l}\text { Corn with beans/ } \\
\text { Maíz con frijol }\end{array}$ & $1.88 \pm 1.59$ & $\begin{array}{l}\text { Apaez et al., 2013, Matus,et al., } \\
2011 .\end{array}$ \\
\hline Campeche & N.S. & $\begin{array}{l}\text { Monoculture (cedar)/ } \\
\text { Monocultivo (cedro) }\end{array}$ & $1.95^{*}$ & Chanatásig et al., 2011. \\
\hline Oaxaca & $\begin{array}{l}\text { Luvisols, Rendzinas and Cambisols (WRB)./Luvi- } \\
\text { soles, Rendzinas y Cambisoles (WRB). }\end{array}$ & $\begin{array}{l}\text { Corn with fruit trees/ } \\
\text { Maíz con árboles frutales }\end{array}$ & $2.20^{*}$ & Vergara \& Etchevers, 2006. \\
\hline Tabasco & Fluvisol (WRB). & $\begin{array}{l}\text { Cedar associated with } \\
\text { mahogany and ginger/Cedro } \\
\text { asociado con caoba y ginger }\end{array}$ & $2.40^{*}$ & Saldaña et al., 2014. \\
\hline Veracruz & Luvisol (WRB). & $\begin{array}{l}\text { Corn with broad beans/ } \\
\text { Maíz con Haba }\end{array}$ & $2.65 \pm 0.24$ & Gamboa \& Galicia, 2011, 2012. \\
\hline Campeche & N.S. & $\begin{array}{l}\text { Home garden with cedar/ } \\
\text { Huerto casero con cedro }\end{array}$ & $2.67^{*}$ & Chanatásig et al,. 2011. \\
\hline Chiapas & $\begin{array}{l}\text { Luvisol, Regosol, Leptosol and Cambisol } \\
\text { (WRB)./Luvisol, Regosol, Leptosol y Cambisol } \\
\text { (WRB). }\end{array}$ & Taungya & $2.89 \pm 1.64$ & $\begin{array}{l}\text { Roncal et al., 2008, Soto et al., } \\
2010 .\end{array}$ \\
\hline Campeche & Luvisol (WRB). & Mango & $2.92^{*}$ & Medina et al,. 2006. \\
\hline Oaxaca & $\begin{array}{l}\text { Luvisols, Rendzinas, Cambisols and Inceptisol } \\
\text { (WRB)./Inceptiso, Luvisol, Rendzico y } \\
\text { Cambisol (WRB). }\end{array}$ & $\begin{array}{l}\text { Conservation corn/ } \\
\text { Maíz coservación }\end{array}$ & $3.60 \pm 0.61$ & $\begin{array}{l}\text { González et al., 2008, Vergara \& } \\
\text { Etchevers, } 2006 .\end{array}$ \\
\hline Chiapas, Oaxaca & $\begin{array}{l}\text { Luvisol, Regosol, Leptosol and Cambisol } \\
\text { (WRB). / Luvisol, Regosol, Leptosol y Cambisol } \\
\text { (WRB). }\end{array}$ & $\begin{array}{l}\text { Shadeless coffee/ } \\
\text { Café sin sombra }\end{array}$ & $4.06 \pm 0.52$ & $\begin{array}{l}\text { Soto et al., 2010, Vergara \& } \\
\text { Etchevers, } 2006 .\end{array}$ \\
\hline Tabasco, Veracruz & $\begin{array}{l}\text { Histosol, Gleysol, Vertisol, Cambisol, Luvisol, } \\
\text { Acrisol, Leptosol and Regosol (WRB)./Histosol, } \\
\text { Gleysol, Vertisol, Cambisol, Luvisol, Acrisol, } \\
\text { Leptosol y Regosol (WRB). }\end{array}$ & Pastureland/Pastizal & $3.95 \pm 3.28$ & $\begin{array}{l}\text { Geissen et al., 2009, Travieso } \\
\text { et al., } 2005 .\end{array}$ \\
\hline $\begin{array}{l}\text { Chiapas, Oaxaca, } \\
\text { Yucatán }\end{array}$ & $\begin{array}{l}\text { Ferrasol, Luvisol, Regosol, Leptosol and } \\
\text { Cambisol (WRB)./Ferrasol, Luvisol, Regosol, } \\
\text { Leptosol y Cambisol (WRB). }\end{array}$ & Milpa & $3.98 \pm 2.23$ & $\begin{array}{l}\text { González et al., 2008, De Jong } \\
\text { et al,. 1999, Matus, et al., 2011, } \\
\text { Roncal et al., 2008, Shangl \& } \\
\text { Tiessen, 2003, Soto et al., } 2010\end{array}$ \\
\hline Oaxaca & $\begin{array}{l}\text { Inceptiso, Luvisol, Rendzico and Cambisol } \\
\text { (WRB). / Inceptiso, Luvisol, Rendzico y } \\
\text { Cambisol (WRB). }\end{array}$ & Shade coffee / Café a la sombra & $3.95 \pm 1.16$ & $\begin{array}{l}\text { González et al,. 2008, Vergara \& } \\
\text { Etchevers, 2006). }\end{array}$ \\
\hline $\begin{array}{l}\text { Campeche, Chiapas, } \\
\text { Oaxaca, Guerrero, } \\
\text { Tabasco, Veracruz }\end{array}$ & $\begin{array}{l}\text { Cambisol, Fluvisol, Phaeozem, Gleysol, } \\
\text { Vertisol, Luvisol, Leptosol, Regosol, Acrisol, } \\
\text { Inceptisols, Rendzinas (WRB); and Typic } \\
\text { Udorthents, Typic Dystrudepts, Hydric Pachic } \\
\text { Melanudand and Typic Hapludand (ST). }\end{array}$ & Corn/Maíz & $4.57 \pm 4.20$ & $\begin{array}{l}\text { Bautista et al., 2012, Campos } \\
\text { 2014, Candelaria et al., 2014, } \\
\text { Cervantes et al., 2014, Geissen } \\
\text { et al., 2009, González et al., } \\
\text { 2008, León et al., 2006, Matus } \\
\text { et al., 2011, Medina et al., 2006, } \\
\text { Mendoza et al., 2003, Ruiz et al., } \\
\text { 2015, Vergara \& Etchevers, } \\
\text { 2006. }\end{array}$ \\
\hline $\begin{array}{l}\text { Oaxaca, Quintana } \\
\text { Roo }\end{array}$ & $\begin{array}{l}\text { Vertisol, Leptosol, Luvisol, Rendzico, } \\
\text { Inceptisol and Cambisol (WRB). / Vertisol, } \\
\text { Leptosol, Luvisol, Rendzico, Inceptisol y Cambisol } \\
\text { (WRB). }\end{array}$ & $\begin{array}{l}\text { Milpa with trees / Milpa con } \\
\text { árboles }\end{array}$ & $4.77 \pm 2.37$ & $\begin{array}{l}\text { Flores et al. 2011, González } \\
\text { et al., } 2008 .\end{array}$ \\
\hline Tabasco & Typic Paleudults (ST). & Pineapple / Piña & $5.80^{*}$ & Wadsworth et al., 1990. \\
\hline Veracruz & $\begin{array}{l}\text { Hydric Pachic Melanudand, Typic Hapludand } \\
\text { (ST). }\end{array}$ & $\begin{array}{l}\text { Corn with potato / Maíz con } \\
\text { papa }\end{array}$ & $6.06^{*}$ & Campos, 2014. \\
\hline Veracruz & $\begin{array}{l}\text { Andosol and Cambisol (WRB); and Typic } \\
\text { Ustivitrand (ST). / Andosol y Cambisol (WRB); y } \\
\text { Typic Ustivitrand (ST). }\end{array}$ & Potato / Papa & $6.52 \pm 2.52$ & Gamboa \& Galicia, 2011, 2012. \\
\hline
\end{tabular}

* Refers to unique data with inability to estimate range. N.S. = authors do not specify soil type. WRB = World Reference Base for Soil Resources (FAO)

ST = Soil Taxonomy (USDA)

* Se refiere a datos únicos con imposibilidad de estimar rango. N.E.= los autores no especifican el tipo de suelo. WRB =World Reference Base for Soil Resources (FAO). ST = Soil Taxonomy (USDA) 
Figure 1. Organic carbon content (\%) by state and crop group.

Figura 1. Contenido de carbono orgánico (\%) por estado y grupo de cultivo.

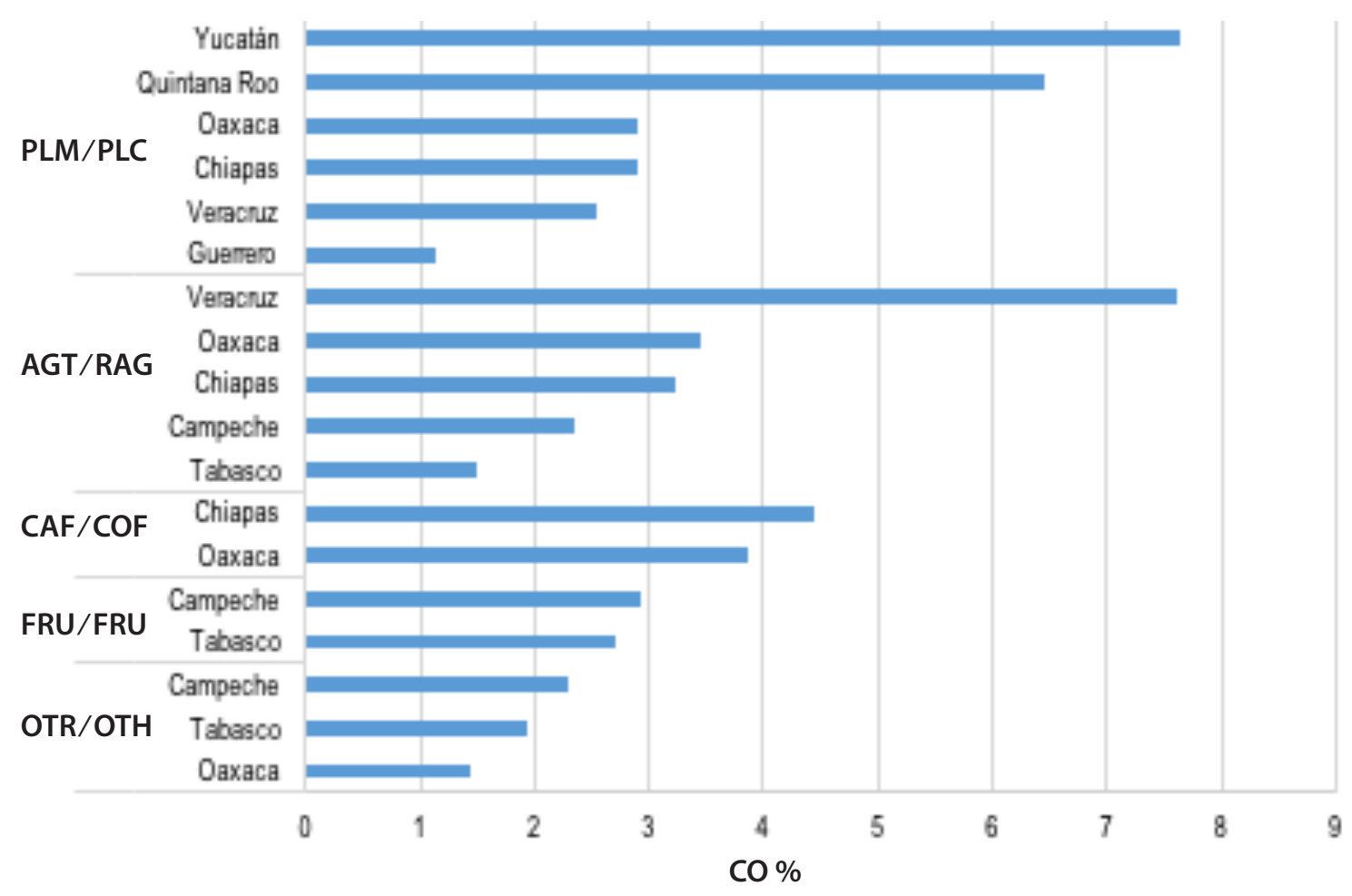

According to the crop groups and their reported SOC, there are no significant differences $(P>0.05)$ between them (Table 2). It is noticeable that the category of rainfed agriculture (RAG) and SOC content is higher compared to the rest of the categories. The crop reported with the highest SOC concentration in soil is corn with $16 \%$ in Veracruz, in Andosol soils, while the one with the lowest concentration was sugarcane with $1.05 \%$ in Tabasco (Campos, 2014, Medina et al., 2006). In the category of other types of crops (OTH), it was found that the crop with the highest SOC concentration is home gardens with cedar and fruits (2.67\%) in the state of Campeche, and the crop with the lowest concentration was Agave angustifolia Haw. $(0.81 \%)$ in the state of Oaxaca. The latter, according to the authors, grows in soils poor in organic matter, nitrogen and phosphorus (Bautista, Carrillo, Amaud, Robles \& de León, 2007, 2015).

Regarding soil types (Supplementary information Appendix 3), it is reported that soils with the highest SOC content with $16.7 \%$ in Veracruz are the so-called hydric pachic melanudand, as well as typic hapludand (Soil Taxonomy), also called Andosols (FAO/ UNESCO). Andosol soils are characterized by con- producción de café, pero no se encontró alguna publicación que refiera el contenido de COS. También, la producción de maíz en condiciones de temporal es una actividad agrícola importante para la mayoría de los agricultores en México, lo que significa la importancia que tiene una buena temporada de lluvias para la agricultura (Conde, Ferrer, \& Orozco, 2006).

Siguiendo la Figura 1 se interpreta que el estado que reporta mayor diversidad agrícola con estudios reportados de COS es Oaxaca, seguido de Chiapas. El valor más alto de COS reportado es para Yucatán y Veracruz de 7.64 y $7.6 \%$, respectivamente. Por otro lado, el de menor COS es Guerrero (1.1\%). Sin embargo, los estados de Yucatán, Quintana Roo y Guerrero revelan un importante rezago de estudios realizados en cuanto al tema, los que se han llevado a cabo son, principalmente, en cultivos asociados con maíz.

De acuerdo con los grupos de cultivos y su COS reportado no existen diferencias significativas $(P>$ 0.05 ) entre estos (Cuadro 2). Es apreciable que la categoría de agricultura de temporal (AGT) y el contenido de $\operatorname{COS}$ es mayor comparado con el resto de las cate- 
Table 2. Organic carbon content by crop group

Cuadro 2. Contenido de carbono orgánico por grupo de cultivos

\begin{tabular}{lcc}
\hline \multicolumn{1}{c}{ Type of crop / Tipo de cultivo } & \% SOC / COS \% & Tukey Significance / Significancia \\
& & Tukey \\
\hline Other types of crops (OTH)/Otros tipos de cultivos (OTR) & $1.89 \pm 0.85$ & $\mathrm{a}$ \\
Fruit trees (FRU)/Frutales (FRU) & $2.76 \pm 2.19$ & $\mathrm{a}$ \\
Polycultures with corn (PLC)/Policultivos con maíz (PLM) & $3.17 \pm 2.01$ & $\mathrm{a}$ \\
Coffee crops (COF) / Cultivos de café (CAF) & $4.01 \pm 0.74$ & $\mathrm{a}$ \\
Rainfed agriculture (RAG)/Agricultura de temporal (AGT) & $4.57 \pm 3.50$ & $\mathrm{a}$ \\
\hline
\end{tabular}

*Equal letters indicate no significant differences.

*Letrasigualesindica sin diferencias significativas.

serving up to $78 \mathrm{Pg}$ of SOC (t) (Martínez et al., 2008), are also easy to cultivate and have good rooting and water storage properties. They are used for a wide variety of crops, such as sugarcane, tobacco, potato, tea, vegetables, wheat, and garden crops (IUSS Working Group WRB, 2006). The soils with the lowest SOC found were the Cambisol type (FAO/UNESCO) with $0.58 \%$ SOC in the state of Veracruz. Cambisols are very thin to deep soils, from sandy loam to silty clay loam textural classes and dark reddish-brown to dark brown on the surface, friable and with drainage that varies from imperfect to well-drained, but with low organic matter content. Cambisols generally make good agricultural land and are used intensively (IUSS Working Group WRB, 2006).

In agroforestry systems with cocoa and Gleysol soil types, up to $34.7 \mathrm{t} \cdot \mathrm{ha}^{-1}$ of SOC are reported (Salvador et al., 2017), while in Vertisol and sugarcane-cultivated soils $12.89 \mathrm{t} \cdot \mathrm{ha}^{-1}$ of SOC are reported (Sánchez et al., 2003), both soil types in the state of Tabasco. The potential of the soils is still high, since according to the Global Soil Organic Carbon Map (FAO \& ITPS, 2018), it is estimated that Gleysol soils have 88.36 t.ha${ }^{1}$ of SOC stored, ranking third in the highest $\mathrm{SOC}$ content stored, while Vertisols rank $23^{\text {rd }}$ of 27 soil types with $30.68 \mathrm{t} \cdot \mathrm{ha}^{-1}$ of SOC.

It should be emphasized that for most studies the SOC evaluation was conducted in the first $30 \mathrm{~cm}$ of depth, in the top soil layer. The first few centimeters of soil are key to agricultural production, and therefore to the food security of the population, since failure to employ good use and management practices results in the loss of $\mathrm{SOC}$, favoring the soil becoming a $\mathrm{CO}_{2}$ emitter and contributing to climate change (Hobley \&Wilson, 2016, Márques et al., 2015). Temperature gorías. El cultivo reportado con mayor concentración de $\operatorname{COS}$ en suelo, es maíz con 16 \% en Veracruz, en suelos Andosoles, mientras que el de menor concentración fue caña con $1.05 \%$ en Tabasco (Campos, 2014; Medina et al., 2006). En la categoría de otros tipos de cultivos (OTR) se encontró que el cultivo con mayor concentración de $\mathrm{COS}$ en suelo es huertos caseros de cedro con frutos (2.67\%) en el estado de Campeche y el cultivo con menor concentración fue Agave angustifolia Haw. (0.81 \%) en el estado de Oaxaca. Este último, según los autores los suelos donde se desarrolla son pobres en términos de materia orgánica, así como también en nitrógeno y fósforo (Bautista, Carrillo, Amaud, Robles, \& de León, 2007, 2015).

Haciendo énfasis en los tipos de suelo (Información complementaria Anexo 3) se reporta que los suelos con más contenido de COS con $16.7 \%$ en Veracruz son los denominados hydric pachic melanudand, así como typic hapludand (Soil Taxonomy) también llamados Andosoles (FAO/UNESCO). Los suelos andosoles se caracterizan por conservar hasta $78 \mathrm{Pg}$ de COS (t) (Martínez et al., 2008), además son fáciles de cultivar y tienen buenas propiedades de enraizamiento y almacenamiento de agua. Son utilizados para una amplia variedad de cultivos, como la caña de azúcar, el tabaco, la papa, el té, verduras, el trigo y los cultivos de huertos (IUSS Working Group WRB, 2006). Los suelos con menor COS que se encontró fue para el tipo Cambisol (FAO/UNESCO) con $0.58 \%$ COS en el estado de Veracruz. Los Cambisoles son suelos muy delgados a profundos, de clases texturales franco arenoso a franco arcillo limosa y colores pardo rojizo oscuro a pardo oscuro en superficie, friables y con drenaje que varía entre imperfecto y bien drenado, pero con bajo contenido de materia orgánica. 
and precipitation are fundamental for the mineralization of SOM, so if there is a change in these factors, a change in $\mathrm{SOC}$ content is to be expected. This is shown in a study by Gómez, Monterroso, Lechuga, Arce, \& Ruiz (2017) on the impact of climate change where it is estimated that there are SOC reductions in the soils. Therefore, research on $\mathrm{SOC}$ content is essential to promote practices that increase crop productivity and thus reduce carbon emissions (Wang et al., 2016).

It should be noted that SOC is linked to the sustainability of agricultural systems by affecting soil properties related to sustained crop yields (Casanova \& Solano, 2011, Charro, Huerga, Navarro, Gil, \& Moyano, 2008). Management practices such as traditional and conservation tillage, soil type and climate directly affect SOC concentration, as well as cause physical degradation, destruction of aggregates and decreased productivity (Paustian, Six, Elliott, \& Hunt, 2000, Wright \& Hons, 2005). Even globally, the ' 4 per mille Soils for Food Security and Climate' initiative is being promoted; it seeks to increase global soil organic matter stocks by 4 per 1000 (or $0.4 \%$ ) in the upper 30$40 \mathrm{~cm}$ of agricultural soils (Minasny et al., 2017). With appropriate soil use and management practices, this goal could be achieved.

Periodically providing organic waste of animal origin favors increased SOC, which would explain the high value (Campos, 2014) reported for Veracruz and for corn (16.7\% SOC). In Chiapas, organic waste of plant origin is incorporated and $4.43 \%$ SOC is reported for shade coffee grown above 1000 masl. When no residues are incorporated, the SOC values found are lower, as in Oaxaca where $3.13 \%$ SOC is reported in soils with shade coffee but on slopes with gradients greater than 30 \% (González, Etchevers, \& Hidalgo, 2008, Soto, Anzueto, Mendoza, Jiménez, \& De Jong, 2010).

Management practices such as conservation tillage, soil retention barriers and agroforestry practices can increase the amount of carbon added to the soil by up to $480 \mathrm{~kg}$ per hectare annually (Álvarez 2005, García-Franco, Albaladejo, Almagro, \& Martínez-Mena, 2015, Hamilton, Wallis, \& Leth, 2014, Scala Junior, La, Figaredo, \& Panosso, 2012). It also promotes soil aggregation through improved binding of soil particles as a result of higher $\mathrm{SOC}$ content (Wright \& Hons, 2005). In Oaxaca, 4.03 and $1.48 \%$ were found in the sowing of corn with
Generalmente son buenas tierras agrícolas y se usan intensivamente (IUSS Working Group WRB, 2006).

En sistemas agroforestales con cacao y con tipo de suelos Gleysol se reporta hasta $34.7 \mathrm{t} \cdot \mathrm{ha}^{-1}$ de COS (Salvador et al., 2017); mientras que en suelos Vertisoles y con cultivo de caña se reportaron 12.89 th ha $^{-1}$ de COS (Sánchez et al., 2003), ambos tipos de suelo en el estado de Tabasco. El potencial de los suelos aún es alto, ya que de acuerdo con el mapa mundial de carbono orgánico del suelo (FAO \& ITPS, 2018), se estima que los suelos Gleysoles tienen almacenado $88.36 \mathrm{t} \cdot \mathrm{ha}^{-1}$ de $\mathrm{COS}$, ocupando el lugar número 3 en mayor contenido de COS almacenado; mientras que los Vertisoles ocupan el lugar 23 de 27 tipos de suelo con $30.68 \mathrm{t} \cdot \mathrm{ha} \mathrm{a}^{-1} \mathrm{de}$ COS.

Cabe subrayar que para la mayoría de los estudios la evaluación del COS se realizó en los primeros $30 \mathrm{~cm}$ de profundidad, en la capa superficial del suelo. Los primeros centímetros del suelo son clave en la producción agrícola, y, por lo tanto, en la seguridad alimentaria de la población, ya que si no se usan buenas prácticas de uso y manejo se provoca la pérdida del COS, favoreciendo a que el suelo se convierta en emisor de $\mathrm{CO}_{2}$ y contribuya al cambio climático (Hobley \& Wilson, 2016; Márques et al., 2015). La temperatura y precipitación son fundamentales para la mineralización de la MOS, por lo que si hay algún cambio en los factores es de esperarse un cambio en el contenido de COS, así lo muestra un estudio de Gómez, Monterroso, Lechuga, Arce, y Ruiz (2017) sobre el impacto del cambio climático en donde se estima que se tengan reducciones de COS en los suelos. De modo que la investigación sobre el contenido de COS es esencial para impulsar prácticas que aumenten la productividad de los cultivos y así reducir emisiones de carbono (Wang et al., 2016).

Cabe señalar que el COS está vinculado con la sustentabilidad de los sistemas agrícolas afectando las propiedades del suelo relacionadas con el rendimiento sostenido de los cultivos (Casanova \& Solano, 2011; Charro, Huerga, Navarro, Gil, \& Moyano, 2008). Las prácticas de manejo como la labranza tradicional y de conservación, tipo de suelo y el clima afectan directamente en la concentración de COS, así como causar degradación física, destrucción de los agregados y disminuir la productividad (Paustian, Six, Elliott, \& Hunt, 2000; Wright \& Hons, 2005). 
conservation and traditional tillage, respectively (Ruiz, Mena, Diego, \& Herrera,2015, Vergara \& Etchevers, 2006).

The conservation of sufficient SOM levels is essential for the biological, chemical and physicochemical functioning of the soil in tropical ecosystems. Appropriate SOM levels ensure soil fertility and minimize agricultural impact on the environment by sequestering carbon (C), reducing erosion and preserving soil biodiversity (Six et al., 2002). Lal (2004) states that $78 \pm 12 \mathrm{Pg}$ of $\mathrm{C}$ are emitted to the atmosphere from the soil. This loss is mainly due to agricultural activity, which is more accelerated in warm humid and sub-humid regions. Agricultural land has high storage potential in conjunction with good management and contributes greatly to the increase in SOC (Conde et al., 2006, Dollinger \& Jose, 2018). For example, reforestation contributes $0.6 \mathrm{t}$ C.ha ${ }^{-1}$.year ${ }^{-1}$, organic amendments 0.5 tons, waste incorporation 0.35 tons, reduced or zero tillage 0.3 tons and crop rotation 0.2 tons $\mathrm{C} \mathrm{ha}^{-1}$.year ${ }^{-1}$, approximately (Minasny et al., 2017).

\section{Potential for future work and research recommendations}

Among the many benefits described, SOC also provides the soil with the nutrients that plants require. However, our results reveal the paucity of information from studies related to SOC in agricultural soils. According to INEGI (2007) and SIAP (2017), the country's southern and southeastern areas have a diversity of crops planted (in the order of 164 reported). However, few crops have been evaluated for their SOC content in soil. Of the total surface area (39 476600 hectares) corresponding to the eight states studied, between 6 and 8.5 million hectares are planted ( $21 \%$ of the total surface area). Thus, we found one crop of 33 reported in Quintana Roo where SOC has been analyzed; one crop of 56 possible in Yucatan; two crops of 46 in Campeche and two of 65 in Chiapas. We found four crops for Oaxaca out of 81 possible, as well as the same number for Veracruz out of 108 reported. In the case of Tabasco, we found seven crops studied out of 49 reported by INEGI (2007) and SIAP (2017). In other words, more studies are needed to cover all the crops reported in the states (Table 3).
Incluso, a nivel global se impulsa la iniciativa 4 x 1000 que busca el aumento anual de carbono orgánico en el suelo, en $0.4 \%$ en los 30-40 cm superiores de los suelos agrícolas (Minasny et al., 2017). Con prácticas de uso y manejo adecuadas para el suelo podría ser posible alcanzar lo que busca la iniciativa.

Aportar periódicamente residuos orgánicos de origen animal favorece el incremento de COS, lo que explicaría el valor alto (Campos, 2014) reportado para Veracruz y para maíz ( $16.7 \%$ COS). En Chiapas se incorporan residuos orgánicos de origen vegetal y se reporta $4.43 \%$ COS en café a la sombra sobre los 1000 msnm. Cuando no se incorporan residuos, los valores encontrados de COS son más bajos, como en Oaxaca donde se reporta $3.13 \%$ en suelos con café a la sombra pero en laderas con pendientes mayores a 30 \% (González, Etchevers, \& Hidalgo, 2008, Soto, Anzueto, Mendoza, Jiménez, \& De Jong, 2010).

Prácticas de manejo como la labranza de conservación, barreras de retención de suelo, prácticas agroforestales, pueden incrementar hasta $480 \mathrm{~kg}$ de C.ha- ${ }^{-1} \cdot$ año $^{-1}$ al suelo (Álvarez 2005; GarcíaFranco, Albaladejo, Almagro, \& Martínez-Mena, 2015; Hamilton, Wallis, \& Leth, 2014; Scala Junior, La, Figaredo, \& Panosso, 2012). Además promueve la agregación del suelo a través de la unión mejorada de las partículas del suelo como resultado de un mayor contenido de COS (Wright \& Hons, 2005). En la siembra de maíz con labranza de conservación y tradicional en Oaxaca se encontró 4.03 y $1.48 \%$, respectivamente (Ruiz, Mena, Diego, \& Herrera, 2015; Vergara \& Etchevers, 2006).

La conservación de niveles suficientes de MOS del suelo es fundamental para el funcionamiento biológico, químico y fisicoquímico del suelo en los ecosistemas tropicales. Los niveles apropiados de MOS aseguran la fertilidad del suelo y minimizan el impacto agrícola en el medio ambiente mediante el secuestro de carbono (C), reduciendo la erosión y preservando la biodiversidad del suelo (Six et al., 2002). Lal, 2004 afirma que se emiten a la atmosfera $78 \pm 12 \mathrm{Pg}$ de $\mathrm{C}$ provenientes del suelo. Pérdida que se debe principalmente a la actividad agrícola, el cual, es más acelerado en regiones cálido húmedas y subhúmedas. Las tierras agrícolas tienen alto potencial de almacenamiento en conjunto con el buen manejo y contribuyen en buena medida al incremento del COS (Conde et al., 2006; Dollinger \& 
Table 3. SOC research needs by crop and state Cuadro 3. Necesidades de investigación de COS por cultivo y entidad

\begin{tabular}{|c|c|c|c|}
\hline $\begin{array}{l}\text { State / } \\
\text { Entidad }\end{array}$ & Spring-Summer & Autumn-Winter & Perennial \\
\hline Campeche & $\begin{array}{l}\text { Palay (unhusked) rice, peanut, } \\
\text { zucchini, green chili, beans, roselle, } \\
\text { jicama, grain sorghum and soybeans./ } \\
\text { Arroz palay, cacahuate, calabacita, } \\
\text { chile verde, frijol, jamaica, jícama, } \\
\text { sorgo grano y soya. }\end{array}$ & $\begin{array}{l}\text { Palay rice, zucchini, green chili, beans, } \\
\text { grain corn, cucumber, watermelon, } \\
\text { grain sorghum, soybeans and tomato./ } \\
\text { Arroz palay, calabacita, chile verde, } \\
\text { frijol, maíz grano, pepino, sandía, } \\
\text { sorgo grano, soya y jitomate. }\end{array}$ & $\begin{array}{l}\text { Avocado, sugarcane, plum, copra, } \\
\text { soursop, lemon, mamey, mandarin, } \\
\text { cashew, nanche, orange, African palm, } \\
\text { papaya, pepper, pineapple, banana, } \\
\text { aloe, Stevia, tamarind, grapefruit, } \\
\text { sapote, chiclero sapote. / } \\
\text { Aguacate, caña de azúcar, ciruela, } \\
\text { copra, guanábana, limón, mamey, } \\
\text { mandarina, marañón, nanche, naranja, } \\
\text { palma africana, papaya, pimienta, } \\
\text { piña, plátano, sábila, Stevia, tamarindo, } \\
\text { toronja, zapote, zapote chiclero. }\end{array}$ \\
\hline
\end{tabular}

Chiapas Sesame, palay rice, peanut, squash, sweet potato, green chili, cabbage, beans, potato, cucumber, watermelon, sorghum, soybeans, tomato, green tomato and wheat./ Ajonjolí, arroz palay, cacahuate, calabaza, camote, chile verde, col, frijol, papa, pepino, sandía, sorgo, soya jitomate, tomate verde y trigo.
Sesame, peanut, squash, onion, green chili, cabbage, elote (ear of corn), beans, grain corn, melon, potato, watermelon, sorghum, soybeans, tobacco, red tomato, green tomato, wheat. /

Ajonjolí, cacahuate, calabaza, cebolla, chile verde, col, elote, frijol, maíz grano, melón, papa, sandía, sorgo, soya, tabaco, tomate rojo, tomate verde, trigo.
Guerrero Sesame, basil, palay rice, fodder oats, peanut, zucchini, squash, sweet potato, onion, green chili, coriander, cabbage, green beans, elote, loofah, beans, gladiola, grain beans, roselle, ginger, jicama, lettuce, margarita, melon, tuberose, nube, okra, pápalo, cucumber, radish, watermelon, sorghum, red tomato, green tomato and zempoalxóchitl./

Ajonjolí, albahaca, arroz palay, avena forrajera, cacahuate, calabacita, calabaza, camote, cebolla, chile verde, cilantro, col, ejote, elote, estropajo, frijol, gladiola, haba grano, jamaica, jenjjibre, jícama, lechuga, margarita, melón, nardo, nube, okra, pápalo, pepino, rábano, sandía, sorgo, tomate rojo, tomate verde y zempoalxóchitl.

Oaxaca Sesame, canary grass, amaranth, pea, oats, peanut, zucchini, sweet potato, barley, onion, pea, green chili, coriander, green beans, beans, gladiola, broad beans, roselle, ginger, melon, tuberose, potato, cucumber, watermelon, sorghum, red tomato, green tomato, wheat, zempoalxóchitl./ Ajonjolí, alpiste, amaranto, arvejón, avena, cacahuate, calabacita, camote, cebada, cebolla, chícharo, chile verde, cilantro, ejote, frijol, gladiola, haba, jamaica, jenjibre, melón, nardo, papa, pepino, sandía, sorgo, tomate rojo, tomate verde, trigo, zempoalxóchitl.
Garlic, sesame, aster, oats, peanut, zucchini, squash, sweet potato, onion, green chili, cabbage, chrysanthemum, green beans, elote, loofah, flor perrito, beans, chickpea, gladiola, huauzontle, jicama, lettuce, corn, melon, tuberose, nube, okra, pápalo, grasses and pastures, cucumber, radish, watermelon solidago, sorghum, tobacco, red tomato, green tomato and cassava. /

Ajo, ajonjolí, aster, avena, cacahuate, calabacita, calabaza, camote, cebolla, chile verde, col, crisantemo, ejote, elote, estropajo, flor perrito, frijol, garbanzo, gladiola, huauzontle, jícama, lechuga, maíz, melón, nardo, nube, okra, pápalo, pastos y praderas, pepino, rábano, sandía, solidago, sorgo, tabaco, tomate rojo, tomate verde y yuca.

Garlic, sesame, oats, peanut, zucchini, sweet potato, barley, onion, pea, green chili, coriander, cabbage, green beans, strawberry, beans, chickpea, gladiola, broad beans, corn, melon, tuberose, cucumber, watermelon, sorghum, red tomato, green tomato, wheat. /

Ajo, ajonjolí, avena, cacahuate, calabacita, camote, cebada, cebolla, chícharo, chile verde, cilantro, col, ejote, fresa, frijol, garbanzo, gladiola, haba, maíz, melón, nardo, pepino, sandía, sorgo, tomate rojo, tomate verde, trigo.
Avocado, cocoa, sugarcane, chayote, plum, copra, peach, guava, rubber, lemon, lychee, macadamia, mamey, mandarin, mango, mangosteen, apple, cashew, nanche, orange, African palm, parlour palm, papaya, grasses and pasture, pear, perón, pepper, pineapple, pine nut, banana, rambutan, Stevia, tamarind, tejocote, sapote./

Aguacate, cacao, caña de azúcar, chayote, ciruela, copra, durazno guayaba, hule hevea, limón, litchi, macadamia, mamey, mandarina, mango, mangostán, manzana, marañón, nanche, naranja, palma africana, palma camedor, papaya, pastos y praderas, pera, perón, pimienta, piña, piñón, plátano, rambután, Stevia, tamarindo, tejocote, zapote.

Agapando, agave, avocado, alfalfa, coffee, sugarcane, apricot, plum, coconut, peach, guaje, soursop, guava, lemon, maguey pulquero, mamey, mandarin, mango, apple, passion fruit, cashew, nanche, orange, loquat, noni, nopalitos, papaya, grass, pear, pineapple, pitahaya, banana, tamarind, grapefruit and sapote./ Agapando, agave, aguacate, alfalfa, café, caña de azúcar, chabacano, ciruela, coco, durazno, guaje, guanábana, guayaba, limón, maguey pulquero, mamey, mandarina, mango, manzana, maracuyá, marañón, nanche, naranja, níspero, noni, nopalitos, papaya, pasto, pera, piña, pitahaya, plátano, tamarindo, toronja y zapote.

Avocado, alfalfa, sugarcane, plum, coconut, peach, pomegranate, rubber, lemon, lychee, mamey, mango, apple, quince, moringa, nanche, orange, nopalitos, walnut, oregano, papaya, grasses and pastures, pear, pepper, pineapple, pitaya, banana, rambutan, Stevia, tamarind, lemongrass, grapefruit, prickly pear, vanilla and sapote./ Aguacate, alfalfa, caña de azúcar, ciruela, coco, durazno, granada, hule, limón, litchi, mamey, mango, manzana, membrillo, moringa, nanche, naranja, nopalitos, nuez, orégano, papaya, pastos y praderas, pera, pimienta, piña, pitaya, plátano, rambután, Stevia, tamarindo, té limón, toronja, tuna, vainilla y zapote. 
Table 3. SOC research needs by crop and state Cuadro 3. Necesidades de investigación de COS por cultivo y entidad. (Cont.)

\begin{tabular}{|c|c|c|c|}
\hline $\begin{array}{l}\text { State / } \\
\text { Entidad }\end{array}$ & Spring-Summer / Primavera-verano & Autumn-Winter / Otoño-invierno & Perennial / Perennes \\
\hline $\begin{array}{l}\text { Quintana } \\
\text { Roo }\end{array}$ & $\begin{array}{l}\text { Peanut, zucchini, squash, green chili, } \\
\text { elote, beans, jicama, corn, cucumber, } \\
\text { watermelon, sorghum, soybeans, red } \\
\text { tomato./ } \\
\text { Cacahuate, calabacita, calabaza, } \\
\text { chile verde, elote, frijol, jícama, maíz, } \\
\text { pepino, sandía, sorgo, soya, tomate } \\
\text { rojo. }\end{array}$ & $\begin{array}{l}\text { Peanut, zucchini, squash, green chili, } \\
\text { elote, beans, jicama, corn, cucumber, } \\
\text { watermelon, sorghum and red } \\
\text { tomato./ } \\
\text { Cacahuate, calabacita, calabaza, } \\
\text { chile verde, elote, frijol, jícama, maíz, } \\
\text { pepino, sandía, sorgo y tomate rojo. }\end{array}$ & $\begin{array}{l}\text { Achiote, sugarcane, coconut, lemon, } \\
\text { mandarin, moringa, orange, papaya, } \\
\text { pineapple, pitahaya, banana and } \\
\text { Stevia./ } \\
\text { Achiote, caña de azúcar, coco, } \\
\text { limón, mandarina, moringa, naranja, } \\
\text { papaya, piña, pitahaya, plátano y } \\
\text { Stevia. }\end{array}$ \\
\hline \multicolumn{3}{|c|}{$\begin{array}{l}\text { Tabasco } \\
\text { Palay rice, squash, sweet potato, chayote, green chili, coriander, melon, cucumber, } \\
\text { watermelon, sorghum, red tomato, cassava. } \\
\text { Palay rice, squash, sweet potato, chayote, green chili, coriander, beans, corn, melon, } \\
\text { cucumber, watermelon, sorghum, tobacco, red tomato and cassava./ } \\
\text { Arroz palay, calabaza, camote, chayote, chile verde, cilantro, melón, pepino, sandía, sorgo, } \\
\text { tomate rojo, yuca. } \\
\text { Arroz palay, calabaza, calabaza, camote, chayote, chile verde, cilantro, frijol, maíz, melón, } \\
\text { pepino, sandía, sorgo, tabaco, tomate rojo y yuca. }\end{array}$} & $\begin{array}{l}\text { Achiote, avocado, coffee, carambola, } \\
\text { copra, soursop, guava, rubber, } \\
\text { lemon, mamey, mandarin, mango, } \\
\text { orange, noni, African palm, pepper, } \\
\text { pitahaya, rambutan, tamarind, } \\
\text { grapefruit and sapote./ } \\
\text { Achiote, aguacate, café, carambolo, } \\
\text { copra, guanábana, guayaba, hule, } \\
\text { limón, mamey, mandarina, mango, } \\
\text { naranja, noni, palma africana, } \\
\text { pimienta, pitahaya, rambután, } \\
\text { tamarindo, toronja y zapote. }\end{array}$ \\
\hline Veracruz & $\begin{array}{l}\text { Garlic, sesame, palay rice, arvejón } \\
\text { oats, broccoli, peanut, zucchini, } \\
\text { squash, sweet potato, barley, chayote, } \\
\text { pea, green chili, ebo, green beans, } \\
\text { strawberries, beans, gladiola, broad } \\
\text { beans, jicama, lettuce, lilium, tuberose, } \\
\text { cucumber, radish, watermelon, } \\
\text { sorghum, soybeans, tobacco, red } \\
\text { tomato, green tomato, wheat, cassava, } \\
\text { carrot, and zempoalxóchitl./ } \\
\text { Ajo, ajonjolí, arroz palay, arvejón, } \\
\text { avena, brócoli, cacahuate, calabacita, } \\
\text { calabaza, camote, cebada, chayote, } \\
\text { chícharo, chile verde, ebo, ejote, fresa, } \\
\text { frijol, gladiola, haba, jícama, lechuga, } \\
\text { lilium, nardo, pepino, rábano, sandía, } \\
\text { sorgo, soya, tabaco, tomate rojo, } \\
\text { tomate verde, trigo, yuca, zanahoria, } \\
\text { zempoalxóchitl. }\end{array}$ & $\begin{array}{l}\text { Chard, garlic, sesame, arvejón, oats, } \\
\text { broccoli, peanut, zucchini, squash, } \\
\text { sweet potato, barley, chayote, pea, } \\
\text { green chili, cabbage, cauliflower, ebo, } \\
\text { green beans, spinach, loofah, beans, } \\
\text { broad beans, jicama, lettuce, corn } \\
\text { melon, potato, cucumber, radish, } \\
\text { watermelon, sorghum, tobacco, red } \\
\text { and green tomato, wheat, cassava and } \\
\text { carrot./ } \\
\text { Acelga, ajo, ajonjolí, arvejón, avena, } \\
\text { brócoli, cacahuate, calabacita, } \\
\text { calabaza, camote, cebada, chayote, } \\
\text { chícharo, chile verde, col, coliflor, ebo, } \\
\text { ejote, espinaca, estropajo, frijol, haba, } \\
\text { jícama, lechuga, maíz, melón, papa, } \\
\text { pepino, rábano, sandía, sorgo, tabaco, } \\
\text { tomate rojo y verde, trigo, yuca y } \\
\text { zanahoria. }\end{array}$ & $\begin{array}{l}\text { Agave, avocado, alfalfa, coffee, } \\
\text { sugarcane,bitter-berry, carambola, } \\
\text { plum, coconut, copra, peach, } \\
\text { soursop, guava, fig, rubber, hevea, } \\
\text { jaca, lemon, lychee, macadamia, } \\
\text { maguey, malanga, mamey, } \\
\text { mandarin, mango, apple, passion } \\
\text { fruit, cashew, nanche, orange, noni, } \\
\text { nopalitos, African palm, parlour } \\
\text { palm, papaya, pear, perón, pepper, } \\
\text { pineapple, pine nut, banana, aloe, } \\
\text { tamarind, tangerine, grapefruit, } \\
\text { prickly pear, vanilla, sapote and } \\
\text { blackberry./ } \\
\text { Agave, aguacate, alfalfa, café, caña de } \\
\text { azúcar, capulín, carambolo, ciruela, } \\
\text { coco, copra, durazno, guanábana, } \\
\text { guayaba, higo, hule, hevea, jaca, } \\
\text { limón, litchi, macadamia, maguey, } \\
\text { malanga, mamey, mandarina, } \\
\text { mango, manzana, maracuyá, } \\
\text { marañón, nanche, naranja, noni, } \\
\text { nopalitos, palma africana, palma } \\
\text { camedor, papaya, pera, perón, } \\
\text { pimienta, piña, piñón, plátano, sábila, } \\
\text { tamarindo, tangerina, toronja, tuna, } \\
\text { vainilla, zapote y zarzamora. }\end{array}$ \\
\hline Yucatán & $\begin{array}{l}\text { Eggplant, peanut, zucchini, squash, } \\
\text { sweet potato, chayote, green chili, } \\
\text { coriander, cabbage, beans, jicama, } \\
\text { lettuce, corn, melon, cucumber, } \\
\text { radish, watermelon, sorghum, } \\
\text { soybeans, red tomato and cassava./ } \\
\text { Berenjena, cacahuate, calabacita, } \\
\text { calabaza, camote, chayote, chile verde, } \\
\text { cilantro, col, frijol, jícama, lechuga, } \\
\text { maíz, melón, pepino, rábano, sandía, } \\
\text { sorgo, soya, tomate rojo y yuca. }\end{array}$ & $\begin{array}{l}\text { Eggplant, zucchini, sweet potato, } \\
\text { chayote, green chili, coriander, } \\
\text { cabbage, green beans, beans, jicama, } \\
\text { lettuce, corn, margarita, melon, } \\
\text { cucumber, radish, watermelon, } \\
\text { sorghum, soybeans, red and green } \\
\text { tomato./ } \\
\text { Berenjena, calabacita, camote, } \\
\text { chayote, chile verde, cilantro, col, ejote, } \\
\text { frijol, jícama, lechuga, maíz, margarita, } \\
\text { melón, pepino, rábano, sandía, sorgo, } \\
\text { soya, tomate rojo y verde }\end{array}$ & $\begin{array}{l}\text { Achiote, avocado, caimito, } \\
\text { sugarcane, carambola, plum, } \\
\text { coconut, guava, henequen, lime, } \\
\text { lemon, mamey, mandarin, mango, } \\
\text { nanche, orange, papaya, pitahaya, } \\
\text { banana, aloe, saramuyo, grapefruit } \\
\text { and sapote./ } \\
\text { Achiote, aguacate, caimito, caña } \\
\text { de azúcar, carambolo, ciruela, coco, } \\
\text { guayaba, henequén, lima, limón, } \\
\text { mamey, mandarina, mango, nanche, } \\
\text { naranja, papaya, pitahaya, plátano, } \\
\text { sábila, saramuyo, toronja y zapote. }\end{array}$ \\
\hline
\end{tabular}

In addition to studying agricultural SOC content, it is important to stabilize or increase reserves, since losses due to inappropriate use or adoption of poor soil management practices can undermine soil quality and structure and increase soil erosion. More in-depth study is needed on: 1) soil moisture
Jose, 2018). Por ejemplo, prácticas como reforestar aporta $0.6 \mathrm{t} \mathrm{C \cdot ha^{-1 } \cdot a n ̃ o}{ }^{-1}$, enmiendas orgánicas 0.5 toneladas, incorporación de residuos 0.35 toneladas, labranza reducida o cero 0.3 toneladas y rotación de cultivos 0.2 toneladas $C$ ha $^{-1} \cdot \mathrm{año}^{-1}$, aproximadamente (Minasny et al., 2017). 
control techniques; 2) increasing SOC through waste or fertilizer management; 3 ) minimum or no-tillage practices, or live barriers to ensure that the soil has sufficient organic cover; 4) crop rotations, planting legumes or improving the crop mix. (FAO, 2017). We believe that the above opens windows for future research.

\section{Conclusions}

Only $12.8 \%$ of the total crops planted in the eight states have been assessed for SOC content. Guerrero is the state that lacks the most studies. The diversity of soil types has also not been covered in the studies. This shows that there is a significant deficit in $\mathrm{SOC}$ knowledge for the agricultural areas of the country's tropical region. There is still an opportunity to conduct research on $\mathrm{SOC}$ storage capacity in this region. In particular, we suggest focusing attention on the effects that may occur due to climate change, in terms of SOC content, soil types and resulting agricultural production.

\section{Acknowledgments}

The authors thank CONACYT for the scholarship, as well as DGIP, CIRENAM, the UACh Soil Science Department, and the anonymous reviewers.

End of English version

\section{References}

Álvarez, R. (2005). A review of nitrogen fertilizer and conservation tillage effects on soil organic carbon storage. Soil Use and Management 21(1):38-52.

Apaez, P., Salvador, J., Ramirez, P., Koch, S., Sosa, E., \& Olalde, V. (2013). Eficiencia agronómica de Nitrógeno y Fósforo en la producción de frijol chino en espaldera de maíz. Terra Latinoamericana 31(4): 285-293.

Bautista, A., Carrillo, R., Arnaud, M. R., Robles, C., \& León, F. De. (2007). Soil fertility properties on Agave angustifolia Haw. plantations. Soil and Tillage Research 96(1-2):342-349.

Bautista, A., Castillo, R. Del, Etchevers, J., Gutiérrez, M., \& Baez, A. (2012). Selection and interpretation of soil quality indicators for forest recovery after

\section{Potencialidades de trabajos futuros y recomendaciones de investigación}

Dentro de los múltiples beneficios descritos, también el COS aporta nutrientes al suelo que las plantas requieren. No obstante, nuestros resultados revelan la escasa información de estudios relacionados al COS en suelos agrícolas. De acuerdo con INEGI (2007) y SIAP (2017), la zona sur y sureste del país cuenta con diversidad de cultivos sembrados (del orden de 164 reportados). Sin embargo, en pocos cultivos se ha evaluado el contenido de COS en suelo. Del total del área superficial (39 476600 hectáreas) que corresponde a los ocho estados estudiados, se siembran entre 6 y 8.5 millones de hectáreas $(21 \%$ del total de la superficie). Así, encontramos un cultivo de 33 reportados en Quintana Roo donde se ha analizado el COS; un cultivo de 56 posibles en Yucatán; dos cultivos de 46 en Campeche y dos de 65 en Chiapas. Cuatro cultivos encontramos para Oaxaca de 81 posibles, así como mismo número para Veracruz de 108 que reporta. En el caso de Tabasco encontramos siete cultivos estudiados de 49 reportados por INEGI (2007) y SIAP (2017). Es decir, se requiere impulsar mayor cantidad de estudios que abarquen la totalidad de cultivos que se reportan en los estados (Cuadro 3).

Además de estudiar el contenido de COS agrícolas es importante estabilizar o incrementar las reservas, ya que las pérdidas debido al uso inapropiado o por adopción de malas prácticas de manejo de los suelos pueden menoscabar la calidad y la estructura del suelo e incrementar su erosión. Es necesario que se estudie más a profundidad sobre 1) técnicas de control de humedad en suelos; 2) aumento del COS mediante manejo de residuos o abonos; 3 ) prácticas de labranza reducida o nula, o barreras vivas para garantizar que el suelo tenga una suficiente cubierta orgánica; 4) rotaciones de cultivos, plantaciones de leguminosas o mejora en combinación de cultivos (FAO, 2017). Consideramos que lo anterior abre ventanas de investigación futura.

\section{Conclusiones}

Del total de cultivos sembrados en los ocho estados únicamente el $12.8 \%$ ha sido evaluado su contenido COS. Guerrero es el estado que más adolece de estudios. La diversidad de tipos de suelos tampoco ha sido cubierta en los estudios. De lo anterior se obser- 
clearing of a tropical montane cloud forest in Mexico. Forest Ecology and Management 277: 74-80.

Bautista, A., López, T., Báez, A., Pérez, R., \& Robles, M. (2015). Dynamics of biochemical soil properties in rainfed Agave angustifolia Haw. Fields in semiarid zone. Pakistan Journal of Botany 47(5): 1909-1920.

Bonan, G. (2008). Forests and climate change: forcings, feedbacks, and the climate benefits of forests. Science 320: 1444-1449.

Campos, A. (2014). Trends in soil respiration on the eastern slope of the Cofre de Perote Volcano (Mexico): Environmental contributions. Catena 114:59-66.

Candelaria, B., Ruiz, O., Pérez, P., Gallardo, F., Vargas, L., Martínez, Á., \& Flota, C. (2014). Sustentabilidad de los agroecosistemas de la microcuenca Paso de Ovejas 1, Veracruz, México. Cuadernos de Desarrollo Rural 11(73): 87-104.

Casanova, F., Petit, J., \& Solorio, J. (2011). Los sistemas agroforestales como alternativa a la captura de carbono en el trópico mexicano. Revista Chapingo Serie Ciencias Forestales y del Ambiente 17(1): 133-143.

Cervantes, V., Gama, J. E., Roldán, I. E., \& Hernández, G. (2014). Basis for implementing restoration strategies: San Nicolás Zoyatlan socialecological system (Guerrero, Mexico). Terra Latinoamericana 32(2): 143-159.

Chanatásig, C., Huerta, E., Rojas, P., Ponce, A., Mendoza J.,... Van Der (2011). Efecto del uso de suelo en las hormigas (Formicidae: Hymenoptera) de Tikinmul, Campeche, México. Acta Zoológica Mexicana 27(2): 441-461.

Charro, E., Huerga, E. C., Navarro, S. H., Gil, J. M., \& Moyano, A. (2008). Estimación del secuestro de carbono en suelos bajos de masas forestales de Pinus halepensis en Castilla y León. Cuadernos de la Sociedad Española de Ciencias Forestales 25: $125-130$.

Conde, C., Ferrer, R., \& Orozco S. (2006). Climate change and climate variability impacts on rainfed agricultural activities and possible adaptation measures. A Mexican case study. Atmosfera 19(3): 181-194.

Dollinger, J., \& Jose, S. (2018). Agroforestry for soil health. Agroforestry Systems 92: 213-219. va un rezago importante en cuanto al conocimiento del COS en las áreas agrícolas de la región tropical del país. Aún hay oportunidad de desarrollar investigaciones sobre la capacidad de almacenamiento de COS de esta región. Particularmente se sugiere dirigir la atención a los efectos que puedan presentarse por cambio climático, tanto en contenido de COS, tipos de suelo y la resultante producción agrícola.

\section{Agradecimientos}

AI CONACYT por la beca, a la DGIP, CIRENAM y Departamento de Suelos de la UACh. A los revisores anónimos.

Fin de la versión en español

FAO. (2017). Directrices voluntarias para la gestión sostenible de los suelos. Organizacion de las Naciones Unidas para la Alimentación y la Agricultura. Roma, Italia.

FAO \& ITPS. (2018). Global soil organic carbon Map (GSOmap). Technical Teport. Rome.

Flores, L., Fedick, S. L., Solleiro, E., Palacios, S., Ortega, P., Sedov, S., \& Osuna, E. (2011). A sustainable system of a traditional precision agriculture in a Maya homegarden: Soil quality aspects. Soil and Tillage Research 113(2): 112-120.

Fuentes, M., Hidalgo, C., Etchevers, J., León, F. de, Guerrero, A., Dendooven, L.,..., Verhulst, N., (2012). Conservation agriculture, increased organic carbon in the top-soil macro-aggregates and reduced soil $\mathrm{CO}_{2}$ emissions. Plant and Soil 355(1-2): 183-197.

Galicia, L., Gamboa Cáceres, A., Cram, S., Chávez Vergara, B., Peña Ramírez, V., Saynes, V., \& Siebe, C. (2015). Almacén y dinámica del carbono orgánico del suelo en bosques templados de México. Terra Latinoamericana 35:1-29.

Gamboa, A. M., \& Galicia, L. (2011). Differential influence of land use/cover change on topsoil carbon and microbial activity in low-latitude temperate forests. Agriculture, Ecosystems and Environment 142(3-4): 280-290.

Gamboa, A. M., \& Galicia, L. (2012). Land-use/cover change effects and carbon controls on volcanic soil profiles in highland temperate forests. Geoderma 170: 390-402. 
Garcia-Franco, N., Albaladejo, J., Almagro, M., \& Martínez-Mena, M. (2015). Beneficial effects of reduced tillage and green manure on soil aggregation and stabilization of organic carbon in a Mediterranean agroecosystem. Soil and Tillage Research 153: 66-75.

Garcia, A., Llosa, J., Laurín, M., Gonzálvez, V., Sanz, M. José, \& Porcuna, J. (2004). Contribución de la agricultura ecológica a la mitigación del cambio climático en comparación con la agricultura convencional. Agroecología 1:75-88.

Geissen, V., Sánchez, R., Kampichler, C., Ramos, R., Sepulveda, A., Ochoa S.,..., Jong B. H. J., De (2009). Effects of land-use change on some properties of tropical soils - An example from Southeast Mexico. Geoderma 151(1): 87-97.

Gómez, J., Monterroso, A., Lechuga, L., Arce, A., \& Ruiz, P. (2017). Impact of climate change on soil organic carbon content on agricultural soils of Mexico. En: Advances in Information and Communication Technologies for Adapting Agriculture to Climate Change (P. Angelov, J. Iglesias \& J. Corrales, eds.), Vol. 687, 58-69.

González, L., Etchevers, J. D., \& Hidalgo, C. (2008). Carbono en suelos de ladera: factores que deben considerarse para determinar su cambio en el tiempo. Agrociencia 42(7): 741-751.

Hamilton, L., Wallis, P., \& Leith, P. (2014). A review of carbon sequestration in vegetation and soils; options, opportunities and barriers for the Southern Slopes Cluster NRM's. Southern Slopes Climate Change Adaptation Research Partnership (SCARP): Victorian Department of Environment and Primary Industries.

Hobley, E. U., \& Wilson, B. (2016). The depth distribution of organic carbon in the soils of eastern Australia. Ecosphere 7(1): 1-21.

Instituto Nacional de Estadística y Geografía (INEGI). (2007). Censo Agrícola, Ganadero y Forestal 2007. Recuperado a partir de https:// www.inegi.org.mx/programas/cagf/2007/ default.html\#Tabulados. Fecha de consulta 5 de Marzo de 2019.

IUSS Working Group WRB. (2006). World reference base for soil resources 2006. World Soil Resources Reports No. 103, Vol. 43. FAO, Rome.
Jong, B. De, Cairns, M., Haggerty, P., Ramírez, N., Ochoa, S., Mendoza, J.,..., González, M., (1999). Land-use change and carbon flux between 1970s and 1990s in central highlands of Chiapas, Mexico. Environmental Management 23(3): 373-385.

Lal, R. (2002). The potential of soils of the tropics to sequester carbon and mitigate the greenhouse effect. Advances in Agronomy 76: 1-30.

Lal, R. (2004). Soil carbon sequestration to mitigate climate change. Geoderma 123(1-2): 1-22.

León, J. A., Gónmez, R., Hernández, S., Álvarez, J. D., \& Palma, D. J. (2006). Mineralización en suelos con incorporación de residuos orgánicos en los altos de Chiapas, México. Universidad y Ciencia 22(2): 163-174.

Malhi, Y., \& Phillips, O. L. (2004). Tropical forests and global atmospheric change: A synthesis. Philosophical Transactions of the Royal Society B: Biological Sciences 359(1443): 549-555.

Márques, J. D. de O., Luizão, F. J., Teixeira, W. G., Sarrazin, M., Ferreira ,S. J. F., Beldini, T. P., \& Márques E. M. de A. (2015). Distribution of Organic Carbon in Different Soil Fractions in Ecosystems of Central Amazonia. Revista Brasileira de Ciência do Solo 39(1): 232-242.

Martínez, E., Fuentes, J., \& Acevedo. E. (2008). Carbono orgánico y propiedades del suelo. Journal of Soil Science and Plant Nutrition 8(1): 68-96.

Martínez, S., Alvarado, A., Zamudio, F., \& Cristóbal, D. (2017). Spatio temporal analysis of forest modeling in Mexico. Revista Chapingo, Serie Ciencias Forestales y del Ambiente 23(1): 5-22.

Matus, F., Hidalgo, C., Monreal, C., Estrada, I., Fuentes, M., \& Etchevers, J. (2011). Land use impacts on physical-based soil organic matter fractions on three hillside Ferrasols in Mexico. Chilean journal of agricultural research 71(2): 283-292.

Medina, J., Volke, V., González, J., Galvis, A., Santiago, M., \& Cortés, J. (2006). Cambios en las propiedades físicas del suelo a través del tiempo en los sistemas de maíz bajo temporal y mango bajo riego en luvisoles del estado de Campeche. Universidad y Ciencia 22(2): 175-189.

Mendoza, J., Karltun, E., \& Olsson, M. (2003). Estimations of amounts of soil organic carbon and fine root carbon in land use and land cover 
classes, and soil types of Chiapas highlands, Mexico. Forest Ecology and Management 177(1-3): 191-206.

Minasny, B., Malone, B. P., McBratney, A. B., Angers ,D. A., Arrouays, D., Chambers A.,..., Chaplot V. (2017). Soil carbon 4 per mille. Geoderma 292: 59-86.

Molina, L. G., Peréz, E. del C. M., Krishnamurty, L. R., Peréz, A. B., \& Miguel, A. M. (2012). Simulación de los cambios de carbono orgánico del suelo en sistema de cultivo con higuerilla por el modelo RothC. Pesquisa Agropecuaria Brasileira 47(11): 1647-1654.

Palm, C., Blanco Canqui, H., DeClerck, F., Gatere, L., \& Grace, P. (2014). Conservation agriculture and ecosystem services: An overview. Agriculture, Ecosystems and Environment 187: 87-105.

Pan, Y., Birdsey, R. A., Fang, J., Houghton, R., Kauppi, P. E., Kurz, W. A.,..., Phillips, O. L. (2011). A large and persistent carbon sink in the world's forests. Science 333: 988-993.

Paustian, K., Six, J., Elliott, E. T., \& Hunt, H. W. (2000). Management options for reducing $\mathrm{CO}_{2}$ emissions from agricultural soils. Biogeochemistry 48(1): 147-163.

Pompa M., \& Sigala, J. Á. (2017). Variation of carbon uptake from forest species in Mexico: a review. Madera y Bosques 23(2):225-235.

Ramos, E., Sol, Á., Guerrero, A., \& Obrador, J. (2011). Arachis pintoi como cobertura de suelo en cultivos de plátano macho (Musa $A A B$ ) en Cárdenas, Tabasco, México. Cultivos tropicales 32(4): 65-70.

Roldán, A., Salinas, J. R., Alguacil, M. M., \& Caravaca, F. (2007). Soil sustainability indicators following conservation tillage practices under subtropical maize and bean crops. Soil and Tillage Research 93(2): 273-282.

Roncal, S. M., Soto L., Castellanos J., Ramírez N. y Jong B. De. (2008). Sistemas agroforestales y almacenamiento de Carbono en comunidades indígenas de Chiapas, México. Interciencia 33(3): 200-206.

Ruiz J., Mena, N., Diego, F., \& Herrera, M. (2015). Productivity and energy efficiency of three tillage systems for maize (Zea mayz L.) production. Revista Facultad de Ingenieria 76: 66-72.

SAGARPA-FAO. (2014). México: el sector agropecuario ante el desafío del cambio climático. México, DF: Secretaría de Agricultura, Ganadería y Pesca.

Saldaña, I., Gómez, R., Rivera, M., Álvarez, J., Ortiz, C., \& Pat, J. (2014). Efecto de abonos orgánicos en la dinámica microbiológica del suelo y producción del Alpinia Purpureta (Vieill) K. Schum. Interciencia 39(11): 809-815.

Salvador, P., Salvador, R., Sánchez, D., López, U., Alejo, G., Valdés, E., \& Gallardo, J. F. (2017). Evolution of soil organic carbon during a cronosequence of transformation from cacao (Theobroma cacao L.) plantation to grassland. Acta Agronomica 66(4): 525-530.

Sánchez, R., Palma, D. J., Obrador ,J. J., \& López, U. (2003). Efecto de los rastrojos sobre las propiedades físicas y químicas de un suelo vertisol y rendimientos de caña de azúcar (Saccharum officinarum L.) En tabasco, méxico. Interciencia 28(7): 404-407.

Saynes, V., Etchevers, J. D., Paz, F,. \& Alvarado, L. O. (2016). Emisiones de gases de efecto invernadero en sistemas agrícolas de México. Terra Latinoamericana 34(1): 83-96.

Scala Junior N. La, Figueiredo, E. B. de, \& Panosso, A. R. (2012). A review on soil carbon accumulation due to the management change of major Brazilian agricultural activities. Brazilian Journal of Biology 72(3): 775-785.

Schmidt, M. W. I., Torn, M. S., Abiven, S., Dittmar, T., Guggenberger, G., Janssens, I. A.,..., Kleber, M. (2011). Persistence of soil organic matter as an ecosystem property. Nature 478(7367): 49-56.

Servicio de Información Agroalimentaria y Pesquera (SIAP). (2017). Anuario Estadístico de la Producción Agrícola. Recuperado a partir de https://nube. siap.gob.mx/cierreagricola/. Fecha de consulta 26 de Marzo de 2019.

Shangl C., \& Tiessen H. (2003). Soil Organic C Sequestration and Stabilization in Karstic Soils of Yucatan. Biogeochemistry 62(2): 177-196.

SIAP. (2017). Anuario Estadístico de la Producción Agrícola. Anuario Estadístico de la Producción Agrícola.

Six, J., Feller, C., Denef, K., Ogle, S., Sa, J. C. de M., \& Albrecht, A. (2002). Soil organic matter, biota and aggregation in temperate and tropical soils. Italian Journal of Agronomy 22:755-775. 
Soto, L., Anzueto, M., Mendoza, J., Jiménez, G., \& Jong, B., De. (2010). Carbon sequestration through agroforestry in indigenous communities of Chiapas, Mexico. Agroforestry Systems 78(1): 39-51.

Travieso, A. C., Moreno, P., \& Campos, A. (2005). Efecto de diferentes manejos pecuarios sobre el suelo y la vegetación en humedales transformados a pastizales. Interciencia 30(1): 12-18.

Vela, G., López, J., \& Rodríguez, M. (2012). Niveles de carbono orgánico total en el Suelo de Conservación del Distrito Federal, centro de México. Investigaciones Geográficas UNAM 77: 1830.

Vergara, M. A., \& Etchevers, J. D. (2006). Relación entre el uso de la tierra y su fertilidad en las laderas de la Sierra Norte de Oaxaca, México. Agrociencia 40(5): 557-567.
Wadsworth, G., Reisenauer, H. M., Gordon, D. R., \& Singer, M. J. (1990). Effects of length of forest fallow on fertility dynamics in a Mexican ultisol. Plant and Soil 122(2): 151-156.

Wang, T., Kang, F., Cheng, X., Han, H., \& Ji, W. (2016). Soil organic carbon and total nitrogen stocks under different land uses in a hilly ecological restoration area of North China. Soil and Tillage Research 163: 176-184.

Wright, A. L., \& Hons, F. M. (2005). Soil carbon and nitrogen storage in aggregates from different tillage and crop regimes. Soil Science Society of America Journal 69(1): 141-147.

Zasada, I. (2011). Multifunctional peri-urban agriculture-A review of societal demands and the provision of goods and services by farming. Land Use Policy 28(4): 639-648.

\section{Appendix / Anexo.}

Appendix 1. Scientific journals that published papers related to the concentration of organic carbon in the soil of different agricultural systems in the Mexican tropics.

Anexo 1. Revistas científicas que publicaron artículos relacionados con la concentración de carbono orgánico en el suelo de diferentes sistemas agrícolas del trópico mexicano.

\begin{tabular}{|c|c|c|c|c|c|}
\hline Journal / Revista & Country/País & $\begin{array}{l}1990- \\
2000\end{array}$ & $\begin{array}{l}2001- \\
2010\end{array}$ & $\begin{array}{l}2011- \\
2018\end{array}$ & Total \\
\hline Acta Agronómica & Colombia & & & 1 & 1 \\
\hline Acta Zoológica Mexicana & México & & & 1 & 1 \\
\hline African Journal of Agricultural Research & Nigeria & & & 1 & 1 \\
\hline Agriculture, Ecosystems and Environment & Netherlands & & 1 & 1 & 2 \\
\hline Agrociencia & México & & 3 & & 3 \\
\hline Agroforestry Systems & Netherlands & & 1 & & 1 \\
\hline Biogeochemistry & Netherlands & & 1 & & 1 \\
\hline Catena & Alemania & & & 1 & 1 \\
\hline Chilean Journal of Agricultural Research & Chile & & & 1 & 1 \\
\hline Cuadernos de desarrollo rural & Colombia & & & 1 & 1 \\
\hline Cultivos Tropicales & Cuba & & & 1 & 1 \\
\hline Environmental Management & $\begin{array}{l}\text { Estados } \\
\text { Unidos }\end{array}$ & 1 & & & 1 \\
\hline Forest Ecology and Management & Netherlands & & 1 & 1 & 2 \\
\hline Geoderma & Netherlands & 1 & 1 & 1 & 3 \\
\hline Interciencia & Venezuela & & 3 & 1 & 4 \\
\hline Agronomy Journal: Organic Agriculture \& Agroecology & $\begin{array}{l}\text { Estados } \\
\text { Unidos }\end{array}$ & & & 1 & 1 \\
\hline Pakistan Journal of Botany & Pakistan & & & 1 & 1 \\
\hline Plant and Soil & Netherlands & 1 & & & 1 \\
\hline Revista Facultad de Ingeniería, Universidad de Antioquía & Colombia & & & 1 & 1 \\
\hline Soil \& Tillage Research & Netherlands & & 1 & 1 & 2 \\
\hline Terra Latinoamericana & México & & 1 & 2 & 3 \\
\hline Universidad y Ciencia:Trópico húmedo & México & & 2 & & 2 \\
\hline Total & & 3 & 15 & 17 & 35 \\
\hline
\end{tabular}


Appendix 2. Soil organic carbon content by state and crop analyzed.

Anexo 2. Contenido de carbono orgánico del suelo por estado y cultivos analizados

\begin{tabular}{|c|c|c|c|c|c|c|c|c|c|}
\hline & Crop / Cultivo & 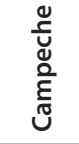 & $\begin{array}{l}\frac{\mathscr{0}}{0} \\
\frac{0}{\tilde{\pi}} \\
\text { บ }\end{array}$ & 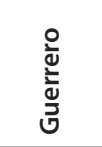 & 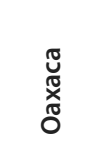 & 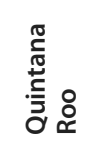 & 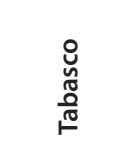 & 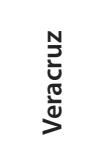 & 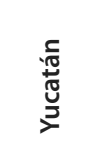 \\
\hline \multirow{9}{*}{$\begin{array}{l}\text { PLC/ } \\
\text { PLM }\end{array}$} & Milpa & & $\begin{array}{l}2.95 \pm \\
1.23\end{array}$ & & $3.45 \pm^{*}$ & & & & $7.64 \pm^{*}$ \\
\hline & Taungya & & $\begin{array}{c}2.89 \pm \\
1.64\end{array}$ & & & & & & \\
\hline & $\begin{array}{l}\text { Milpa with trees/ } \\
\text { Milpa con árboles }\end{array}$ & & & & $3.09 \pm$ & $6.44 \pm^{*}$ & & & \\
\hline & $\begin{array}{l}\text { Corn with trees/ } \\
\text { Maíz con árboles }\end{array}$ & & & & 2.20 & & & & \\
\hline & $\begin{array}{l}\text { Corn with beans/ } \\
\text { Maíz con frijoles }\end{array}$ & & & $1.14 \pm^{*}$ & $3.01 *$ & & & & \\
\hline & $\begin{array}{l}\text { Corn associated with oats } \\
\text { and broad beans/Maíz } \\
\text { asociado con Avena y Haba }\end{array}$ & & & & & & & & \\
\hline & $\begin{array}{l}\text { Corn with broad beans/ } \\
\text { Maíz con haba }\end{array}$ & & & & & & & $\begin{array}{l}2.65 \pm \\
0.24\end{array}$ & \\
\hline & $\begin{array}{l}\text { Corn with potato/ } \\
\text { Maíz con papa }\end{array}$ & & & & & & & $6.06 \pm^{*}$ & \\
\hline & Corn/Maíz & $2.36^{*}$ & $\begin{array}{c}3.24 \pm \\
0.38\end{array}$ & N.E. & $\begin{array}{c}3.60 \pm \\
1.53\end{array}$ & & $1.85^{*}$ & $\begin{array}{c}7.56 \pm \\
8.22\end{array}$ & \\
\hline \multirow{4}{*}{$\begin{array}{l}\text { RAG / } \\
\text { AGT }\end{array}$} & $\begin{array}{l}\text { Conservation corn/ } \\
\text { Maíz de conservación }\end{array}$ & & & & $\begin{array}{c}3.60 \pm \\
0.61\end{array}$ & & & & \\
\hline & Pastureland/Pastizal & & & & & & 1.63 & $6.27^{*}$ & \\
\hline & Sugarcane/Caña & & & & & & $1.25 \pm 0.36$ & & \\
\hline & Potato/Papa & & & & & & & $\begin{array}{c}6.53 \pm \\
2.51\end{array}$ & \\
\hline \multirow{5}{*}{$\begin{array}{l}\text { OTH / } \\
\text { OTR }\end{array}$} & $\begin{array}{l}\text { Agave angustifolia Haw./ } \\
\text { Agave angustifolia Haw. }\end{array}$ & & & & $\begin{array}{l}1.64 \pm \\
1.17\end{array}$ & & & & \\
\hline & AFS & & & N.E. & & & $1.46^{*}$ & & \\
\hline & $\begin{array}{l}\text { Cedar associated with } \\
\text { mahogany and ginger }\end{array}$ & & & & & & $2.40^{*}$ & & \\
\hline & Home garden (cedar, fruits) & 2.67 & & & & & & & \\
\hline & Monoculture (cedar) & 1.95 & & & & & & & \\
\hline \multirow{3}{*}{$\begin{array}{l}\text { COF/ } \\
\text { CAF }\end{array}$} & Shade coffee & & $4.43^{*}$ & & $\begin{array}{l}3.87 \pm \\
0.833\end{array}$ & & & & \\
\hline & Shadeless coffee & & & & & & & & \\
\hline & Mango & $2.92^{*}$ & & & & & & & \\
\hline \multirow{3}{*}{ FRU } & Banana with A. pintoi & & & & & & $1.18^{*}$ & & \\
\hline & Papaya, citrus & & & & & & $1.12^{*}$ & & \\
\hline & Pineapple & & & & & & $5.80^{*}$ & & \\
\hline
\end{tabular}

* Refers to unique data with inability to estimate range / * Se refiere a datos únicos con imposibilidad de estimar rango 
Appendix 3. Soil organic carbon content per crop analyzed.

Anexo 3. Contenido de carbono orgánico del suelo por cultivo analizado.

\begin{tabular}{|c|c|c|c|c|}
\hline State & $\begin{array}{l}\text { Crop } \\
\text { classification }\end{array}$ & Crop & $\%$ OC & Soil type \\
\hline Veracruz & PLC/PLM & $\begin{array}{l}\text { Corn associated with oats and broad } \\
\text { beans / Maíz asociado con avena y } \\
\text { haba }\end{array}$ & 0.58 & $\begin{array}{l}\text { Andosol and Cambisol (WRB)/Andosol y Cambisol } \\
\text { (WRB) }\end{array}$ \\
\hline Veracruz & $\mathrm{PLC} / \mathrm{PLM}$ & $\begin{array}{l}\text { Corn associated with oats and broad } \\
\text { beans / Maíz asociado con avena y } \\
\text { haba }\end{array}$ & 0.75 & $\begin{array}{l}\text { Andosol and Cambisol (WRB) / Andosol y Cambisol } \\
\text { (WRB) }\end{array}$ \\
\hline Guerrero & PLC/PLM & Milpa & 0.75 & N.S. \\
\hline Oaxaca & OTH / OTR & Agave angustifolia Haw. & 0.81 & $\begin{array}{l}\text { Leptosol and Regosol (WRB) / Leptosol y Regosol } \\
\text { (WRB) }\end{array}$ \\
\hline Tabasco & $\mathrm{RAG} / \mathrm{AGT}$ & Sugarcane/Caña & 0.99 & Vertisol (WRB) \\
\hline Tabasco & FRU & $\begin{array}{l}\text { Papaya with citrus / Papaya con } \\
\text { citrus }\end{array}$ & 1.12 & $\begin{array}{l}\text { Gleysol, Vertisol, Cambisol, Luvisol, Acrisol, Leptosol } \\
\text { and Regosol (WRB) / Gleysol, Vertisol, Cambisol, } \\
\text { Luvisol, Acrisol, Leptosol y Regosol (WRB) }\end{array}$ \\
\hline Tabasco & FRU & $\begin{array}{l}\text { Banana with A. pintoi / Plátano con } \\
\text { A. pintoi }\end{array}$ & 1.18 & Fluvisol (WRB) \\
\hline Tabasco & OTH / OTR & Cocoa AFS/SAF cacao & 1.46 & Gleysol (WRB) \\
\hline Oaxaca & $\mathrm{RAG} / \mathrm{AGT}$ & Corn/Maíz & 1.48 & $\begin{array}{l}\text { Cambisol, Fluvisol and Phaeozem (WRB) / Cambisol, } \\
\text { Fluvisol y Phaeozem (WRB) }\end{array}$ \\
\hline Tabasco & RAG/ AGT & Sugarcane/Caña & 1.51 & $\begin{array}{l}\text { Gleysol, Vertisol, Regosol, Luvisol and Leptosol } \\
\text { (WRB)/Gleysol, Vertisol, Regosol, Luvisol y Leptosol } \\
\text { (WRB) }\end{array}$ \\
\hline Chiapas & PLC/PLM & Milpa & 1.53 & N.S. \\
\hline Tabasco & RAG / AGT & Pastureland/Pastizal & 1.64 & $\begin{array}{l}\text { Gleysol, Vertisol, Cambisol, Luvisol, Acrisol, Leptosol } \\
\text { and Regosol (WRB) / Gleysol, Vertisol, Cambisol, } \\
\text { Luvisol, Acrisol, Leptosol y Regosol (WRB) }\end{array}$ \\
\hline Chiapas & PLC / PLM & Taungya & 1.73 & Regosol (WRB) \\
\hline Tabasco & $\mathrm{RAG} / \mathrm{AGT}$ & Corn/Maíz & 1.85 & $\begin{array}{l}\text { Gleysol, Vertisol, Cambisol, Luvisol, Acrisol, Leptosol } \\
\text { and Regosol (WRB) / Gleysol, Vertisol, Cambisol, } \\
\text { Luvisol, Acrisol, Leptosol y Regosol (WRB) }\end{array}$ \\
\hline Campeche & OTH/ OTR & $\begin{array}{l}\text { Monoculture (cedar) / Monocultivo } \\
\text { (cedro) }\end{array}$ & 1.95 & N.S. \\
\hline Oaxaca & PLC / PLM & $\begin{array}{l}\text { Corn with fruit trees / Maíz con } \\
\text { árboles frutales }\end{array}$ & 2.20 & $\begin{array}{l}\text { Luvisol, Leptosol and Cambisol (WRB) / Luvisol, } \\
\text { Leptosol y Cambisol (WRB) }\end{array}$ \\
\hline Veracruz & RAG / AGT & Potato/Papa & 2.30 & Typic Ustivitrands (ST) \\
\hline Campeche & $\mathrm{RAG} / \mathrm{AGT}$ & Corn/Maíz & 2.36 & Luvisol (WRB) \\
\hline Tabasco & OTH/ OTR & $\begin{array}{l}\text { Cedar associated with mahogany } \\
\text { and ginger / Cedro asociado con } \\
\text { caoba y ginger }\end{array}$ & 2.40 & Fluvisol (WRB) \\
\hline Oaxaca & OTH/ OTR & Agave angustifolia Haw. & 2.47 & $\begin{array}{l}\text { Leptosol and Regosol (WRB) / Leptosol y Regosol } \\
\text { (WRB) }\end{array}$ \\
\hline Veracruz & PLC / PLM & $\begin{array}{l}\text { Corn with broad beans / Maíz con } \\
\text { Haba }\end{array}$ & 2.48 & Luvisol (WRB) \\
\hline Campeche & OTH/ OTR & $\begin{array}{l}\text { Home garden with cedar / Huerto } \\
\text { casero con cedro }\end{array}$ & 2.67 & N.S. \\
\hline Chiapas & RAG/ AGT & Corn / Maíz & 2.80 & $\begin{array}{l}\text { Leptosol and Cambisol (WRB) / Leptosol and } \\
\text { Cambisol (WRB) }\end{array}$ \\
\hline Veracruz & $\mathrm{PLC} / \mathrm{PLM}$ & $\begin{array}{l}\text { Corn with broad beans / Maíz con } \\
\text { Haba }\end{array}$ & 2.82 & Luvisol (WRB) \\
\hline Campeche & FRU & Mango & 2.92 & Luvisol (WRB) \\
\hline Oaxaca & PLC/PLM & Corn with beans/Maíz con Haba & 3.01 & N.S. \\
\hline Oaxaca & PLC / PLM & Milpa with trees /Milpa con árboles & 3.10 & Inceptisols (WRB) \\
\hline Oaxaca & COF & Shade coffee/Café con sombra & 3.13 & Inceptisols (WRB) \\
\hline
\end{tabular}


Appendix 3. Soil organic carbon content per crop analyzed.

Anexo 3. Contenido de carbono orgánico del suelo por cultivo analizado. (Cont.)

\begin{tabular}{|c|c|c|c|c|}
\hline State & $\begin{array}{c}\text { Crop } \\
\text { classification }\end{array}$ & Crop & $\% \mathrm{OC}$ & Soil type \\
\hline Oaxaca & RAG / AGT & $\begin{array}{l}\text { Conservation corn/Maíz } \\
\text { conservación }\end{array}$ & 3.17 & Inceptisols (WRB) \\
\hline Chiapas & RAG / AGT & Corn/Maíz & 3.40 & Phaeozem (WRB) \\
\hline Oaxaca & PLC/PLM & Milpa & 3.45 & Ferrasol (WRB) \\
\hline Chiapas & RAG / AGT & Corn/Maíz & 3.53 & Acrisol (WRB) \\
\hline Oaxaca & RAG / AGT & Corn/Maíz & 3.54 & Inceptisols (WRB) \\
\hline Chiapas & PLC/ PLM & Milpa & 3.66 & $\begin{array}{l}\text { Luvisol, Regosol, Leptosol and Cambisol (WRB) / } \\
\text { Luvisol, Regosol, Leptosol y Cambisol (WRB) }\end{array}$ \\
\hline Chiapas & $\mathrm{PLC} / \mathrm{PLM}$ & Milpa & 3.66 & $\begin{array}{l}\text { Luvisol, Regosol, Leptosol and Cambisol (WRB) / } \\
\text { Luvisol, Regosol, Leptosol y Cambisol (WRB) }\end{array}$ \\
\hline Oaxaca & $\mathrm{COF} / \mathrm{CAF}$ & Shadeless coffee / Café con sombra & 3.70 & $\begin{array}{l}\text { Luvisol, Leptosol and Cambisol (WRB) / Luvisol, } \\
\text { Leptosol and Cambisol (WRB) }\end{array}$ \\
\hline Oaxaca & RAG / AGT & Conservation corn & 4.03 & $\begin{array}{l}\text { Luvisol, Leptosol and Cambisol (WRB) / Luvisol, } \\
\text { Leptosol and Cambisol (WRB) }\end{array}$ \\
\hline Chiapas & $\mathrm{PLC} / \mathrm{PLM}$ & Taungya & 4.05 & $\begin{array}{l}\text { Luvisol, Regosol, Leptosol and Cambisol (WRB) / } \\
\text { Luvisol, Regosol, Leptosol y Cambisol (WRB) }\end{array}$ \\
\hline Oaxaca & RAG / AGT & Corn / Maíz & 4.36 & $\begin{array}{l}\text { Luvisol, Leptosol and Cambisol (WRB) Andosol } \\
\text { and Cambisol (WRB) / Luvisol, Leptosol y Cambisol } \\
\text { (WRB) }\end{array}$ \\
\hline Chiapas & $\mathrm{COF} / \mathrm{CAF}$ & Shadeless coffee/Café a la sombra & 4.43 & $\begin{array}{l}\text { Luvisol, Regosol, Leptosol and Cambisol (WRB) / } \\
\text { Luvisol, Regosol, Leptosol y Cambisol (WRB) }\end{array}$ \\
\hline Oaxaca & $\mathrm{COF} / \mathrm{CAF}$ & Shade coffee/Café a la sombra & 4.78 & $\begin{array}{l}\text { Luvisol, Leptosol and Cambisol (WRB) / Luvisol, } \\
\text { Leptosoly Cambisol (WRB) }\end{array}$ \\
\hline Oaxaca & RAG / AGT & Corn/Maíz & 5.00 & $\begin{array}{l}\text { Typic Udorthents and Typic Dystrudepts (ST)/Typic } \\
\text { Udorthents y Typic Dystrudepts (ST) }\end{array}$ \\
\hline Veracruz & RAG / AGT & Corn/Maíz & 5.26 & N.S. \\
\hline Tabasco & FRU & Pineapple/Piña & 5.80 & Typic Paleudults (ST) \\
\hline Veracruz & $\mathrm{PLC} / \mathrm{PLM}$ & Corn with potato / Maíz conpapa & 6.06 & $\begin{array}{l}\text { Hydric Pachic Melanudand and Typic Hapludand } \\
\text { (ST)/Hydric Pachic Melanudand y Typic Hapludand } \\
\text { (ST) }\end{array}$ \\
\hline Veracruz & RAG / AGT & Pastureland /Pastizal & 6.28 & Histosol and Gleysol (WRB)/ Histosol y Gleysol (WRB) \\
\hline Quintana Roo & $\mathrm{PLC} / \mathrm{PLM}$ & Milpa with trees /Milpa con árboles & 6.44 & $\begin{array}{l}\text { Luvisol, Vertisol, Cambisol and Leptosol (WRB) / } \\
\text { Luvisol, Vertisol, Cambisol y Leptosol (WRB) }\end{array}$ \\
\hline Veracruz & RAG / AGT & Potato /Papa & 6.96 & $\begin{array}{l}\text { Andosol and Cambisol (WRB) / Andosol y Cambisol } \\
\text { (WRB) }\end{array}$ \\
\hline Veracruz & RAG / AGT & Potato/Papa & 6.96 & $\begin{array}{l}\text { Andosol and Cambisol (WRB) / Andosol y Cambisol } \\
\text { (WRB) }\end{array}$ \\
\hline Veracruz & RAG / AGT & Potato/Papa & 7.35 & $\begin{array}{l}\text { Andosol and Cambisol (WRB) / Andosol yCambisol } \\
\text { (WRB) }\end{array}$ \\
\hline Yucatán & PLC / PLM & Milpa & 7.64 & N.S. \\
\hline Veracruz & RAG / AGT & Potato/Papa & 9.06 & $\begin{array}{l}\text { Andosol and Cambisol (WRB) / Andosol y Cambisol } \\
\text { (WRB) }\end{array}$ \\
\hline Veracruz & RAG / AGT & Corn/Maíz & 16.70 & $\begin{array}{l}\text { Hydric Pachic Melanudand and Typic Hapludand (ST) } \\
\text { /Hydric Pachic Melanudand y Typic Hapludand (ST) }\end{array}$ \\
\hline Guerrero & RAG / AGT & Corn/Maíz & N.S. & N.S. \\
\hline Guerrero & OTH/OTR & AFS/SAF & N.S. & N.S. \\
\hline
\end{tabular}

Soil classification: WRB = World Reference Base for Soil Resources (FAO); ST = Soil Taxonomy (USDA).

Clasificación de suelos: WRB = World Reference Base for Soil Resources (FAO); ST = Soil Taxonomy (USDA). 
